Aquatic Plant Control Research Program

\title{
Early Season Applications of Fluridone for Control of Curlyleaf Pondweed
}

Angela G. Poovey, Lee Ann M. Glomski,

December 2010

Michael D. Netherland, and John G. Skogerboe 


\section{Early Season Applications of Fluridone for Control of Curlyleaf Pondweed}

Angela G. Poovey, Lee Ann M. Glomski, Michael D. Netherland, and

John G. Skogerboe

Environmental Laboratory

U.S. Army Engineer Research and Development Center 3909 Halls Ferry Road

Vicksburg, MS 39180

Final report

Approved for public release; distribution is unlimited.

Prepared for U.S. Army Corps of Engineers

Washington, DC 20314-1000

and Minnesota Department of Natural Resources

St. Paul, MN 55155 


\begin{abstract}
Widespread in the Great Lakes region, curlyleaf pondweed (Potamogeton crispus L.) is an exotic submersed plant that forms dense monotypic stands, and is reported to restrict recreation, suppress native plant populations, and increase internal phosphorus cycling. Because preventing new turion formation is the key to long-term management of this aquatic weed, the effect of fluridone applications on curlyleaf pondweed growth and vegetative reproduction was evaluated in two greenhouse studies. Herbicide doses ranged from 0.5 to $6 \mu \mathrm{g}$ ai $\mathrm{L}^{-1}$, and were applied to plants of different growth stages for varying exposure times. Fluridone doses $\geq 5 \mu \mathrm{g}$ ai $\mathrm{L}^{-1}$ that were maintained for at least 28 days before degrading to $\leq 2 \mu \mathrm{g}$ ai $\mathrm{L}^{-1}$ inhibited both shoot growth and turion production. Treatments of 3 and $4 \mu \mathrm{g}$ ai $\mathrm{L}^{-1}$ that degraded to $\leq 2 \mu \mathrm{g}$ ai $\mathrm{L}^{-1}$ after 28 days reduced turion number, but not shoot biomass. All treatments $\leq 2 \mu \mathrm{g}$ ai $\mathrm{L}^{-1}$ were comparable to the reference. Although young plants that were $<15 \mathrm{~cm}$ at herbicide application remained below the water surface, they produced the same amount of turions as mature plants that were $>15 \mathrm{~cm}$ at the time of application. Sprouting tests determined that turions from all fluridone treatments were viable. Based on these results, strategies for curlyleaf pondweed management may include fluridone applications to young plants using rates that would curtail turion production and either prevent or limit nuisance shoot growth.
\end{abstract}

DISCLAIMER: The contents of this report are not to be used for advertising, publication, or promotional purposes. Citation of trade names does not constitute an official endorsement or approval of the use of such commercial products. All product names and trademarks cited are the property of their respective owners. The findings of this report are not to be construed as an official Department of the Army position unless so designated by other authorized documents. 


\section{Contents}

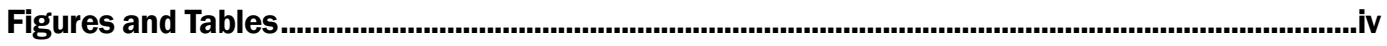

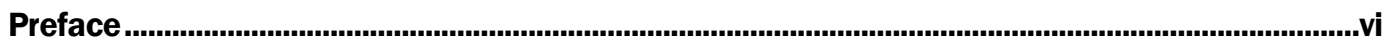

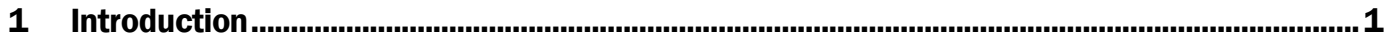

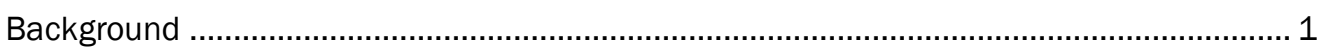

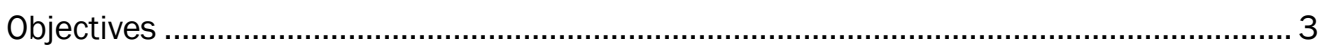

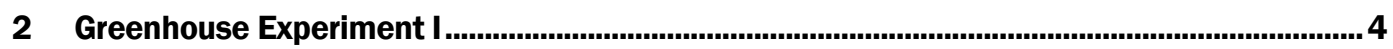

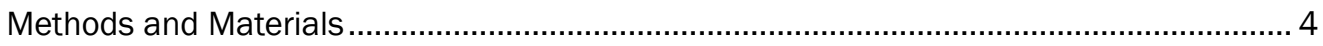

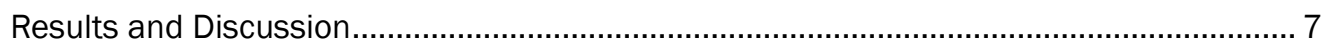

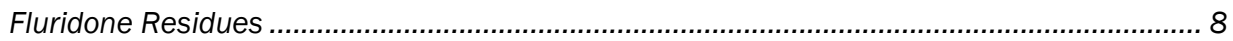

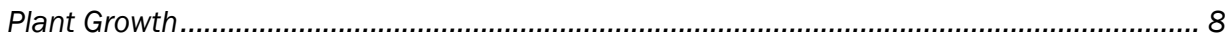

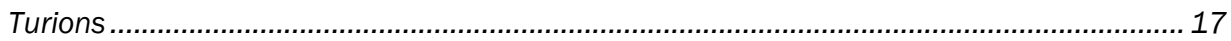

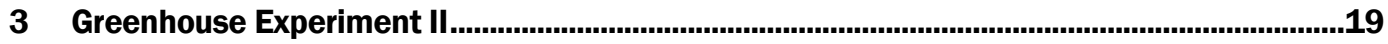

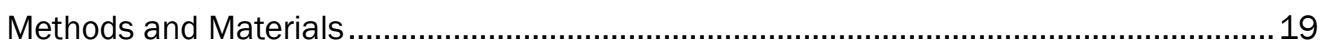

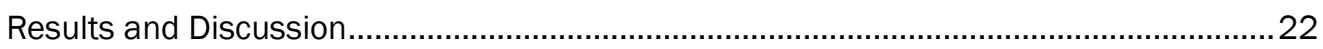

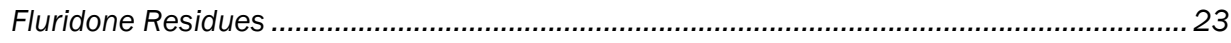

Young Plant Growth and Turion Production..................................................................... 23

Mature Plant Growth and Turion Production......................................................................... 27

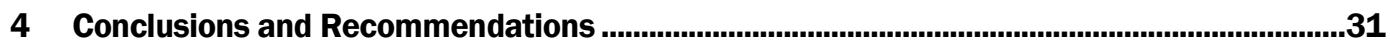

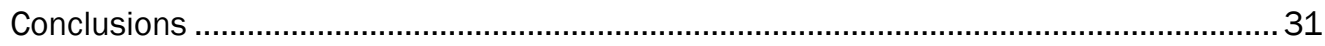

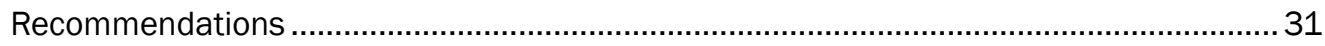

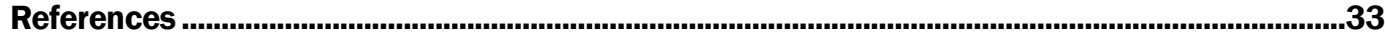

Report Documentation Page 


\section{Figures and Tables}

\section{Figures}

Figure 1. Temperatures taken in greenhouse water bath tanks.

Figure 2. Shoot biomass (g), root biomass (g) and number of turions (mean \pm 1 SE) collected from tall curlyleaf pondweed plants at 70 days after fluridone application

Figure 3. Shoot length (mean $\pm 1 \mathrm{SE} \mathrm{cm}$ ) of tall curlyleaf pondweed plants after fluridone application.

Figure 4. Shoot biomass (g), root biomass (g) and number of turions (mean $\pm 1 \mathrm{SE}$ ) collected from medium curlyleaf pondweed plants at 70 days after fluridone application..

Figure 5 . Shoot length (mean $\pm 1 \mathrm{SE} \mathrm{cm}$ ) of medium curlyleaf pondweed plants after fluridone application.

Figure 6. Shoot biomass (g), root biomass (g) and number of turions (mean $\pm 1 \mathrm{SE}$ ) collected from short curlyleaf pondweed plants at 70 days after fluridone application.

Figure 7. Shoot length (mean $\pm 1 \mathrm{SE} \mathrm{cm}$ ) of short curlyleaf pondweed plants after fluridone application.

Figure 8. Temperatures in greenhouse water baths for Block 1: Young Plants (Tank 12) and Block 2: Mature Plants (Tank 18) from 15 December 2004 through 24 March 2005.

Figure 9. Mean ( $\pm 1 \mathrm{SE}$ ) shoot biomass (g) collected from young curlyleaf pondweed plants at A) 28 days after fluridone treatment (DAT), B) 56 DAT, and C) 72 DAT .

Figure 10. Shoot length (mean $\pm 1 \mathrm{SE} \mathrm{cm}$ ) of young curlyleaf pondweed plants after fluridone application.

Figure 11. Mean ( $\pm 1 \mathrm{SE}$ ) shoot biomass (g) collected from mature curlyleaf pondweed plants at A) 28 days after fluridone treatment (DAT) and B) 49 DAT.

Figure 12. Shoot length (mean $\pm 1 \mathrm{SE} \mathrm{cm}$ ) of mature curlyleaf pondweed plants after fluridone application.

\section{Tables}

Table 1. Daylength and water temperature adjustments to simulate spring field conditions in southern Minnesota.

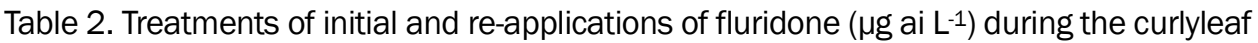
pondweed study, based on actual herbicide residue data.

Table 3. Aqueous fluridone concentrations in aquaria at 2, 28, 30, 56, 58, and 70 days after treatment (DAT).

Table 4. Concentrations of phytoene and $\beta$-carotene (mean $\pm 1 \mathrm{SE} \mu \mathrm{g} \mathrm{g} \mathrm{FW}-1$ ) in curlyleaf pondweed shoots 28 and 56 days after treatment (DAT) of fluridone..

Table 5. Number of axillary, stem and hard stem turions (mean $\pm 1 \mathrm{SE}$ ) produced by curlyleaf pondweed plants after 70-day exposure to fluridone.

Table 6. Daylength and water temperature adjustments to simulate spring field conditions in southern Minnesota.

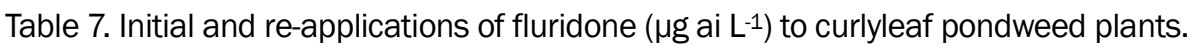


Table 8. Aqueous fluridone concentrations in aquaria 2 days after initial, second and third

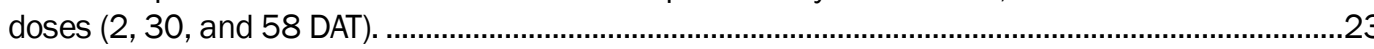

Table 9. Mean ( $\pm 1 \mathrm{SE}$ ) concentrations of phytoene and $\beta$-carotene ( $\left.\mu \mathrm{g} \mathrm{g} \mathrm{FW}^{-1}\right)$ in curlyleaf pondweed shoots after exposure to fluridone..

Table 10. Number of axillary, stem and hard stem turions (mean $\pm 1 \mathrm{SE}$ ) produced by young and mature curlyleaf pondweed plants after 72 and 49 days exposure to fluridone, respectively 


\section{Preface}

The work reported herein was conducted as part of the Aquatic Plant Control Research Program (APCRP). The APCRP is sponsored by Headquarters, U.S. Army Corps of Engineers (HQUSACE), and is assigned to the U.S. Army Engineer Research and Development Center (ERDC) under the purview of the Environmental Laboratory (EL), Vicksburg, MS. Funding was provided under Department of the Army Appropriation No. 96X3122, Construction General and the Minnesota Department of Natural Resources. The APCRP is managed under the Invasive Species Center, Dr. Al Cofrancesco, Director. Robert C. Gunkel, J r. and Dr. Linda Nelson served as Program Managers of APCRP. Program monitor during this study was Timothy R. Toplisek, HQUSACE.

The Principal Investigator of this work was Angela G. Poovey, Environmental Processes Branch (EPB), Environmental Processes and Engineering Division (EPED), EL, ERDC. This work was conducted and the report prepared by Poovey, Lee Ann M. Glomski, Dr. Michael D. Netherland, and J ohn G. Skogerboe, EPB.

Technical reviews of this report were provided by Dr. Kurt D. Getsinger, EPB, and Chip Welling, Minnesota Department of Natural Resources, St. Paul, MN. The authors thank Anne Stewart, CSC, Vicksburg, MS, for plant tissue analyses and Alicia Staddon, SePRO Corporation, Carmel, IN, for water residue analyses.

This work was performed under the general supervision of Dr. Beth C. Fleming, Director, EL; Dr. Richard E. Price, Chief, EPED; and Dr. Richard F. Lance, Chief, EPB.

At the time of publication of this report, Dr. J effery P. Holland was Director of ERDC. COL Gary E. J ohnston, EN, was Commander and Executive Director. 


\section{Introduction}

\section{Background}

Curlyleaf pondweed (Potamogeton crispus L.) is an exotic submersed aquatic weed that is widespread in the lakes of Minnesota, Wisconsin, Michigan, and other northern tier states. It becomes a nuisance when it forms a dense or monotypic stand that covers the water surface, usually in late spring or early summer as water temperatures warm. Plant senescence occurs by late summer, leading to a large-scale release of nutrients that often results in algal blooms.

If chemical treatments are applied in late spring or early summer, after turions have formed, these applications probably have little impact on reducing the viability and recovery of the plant the following season (Woolf and Madsen 2003). Reproductive propagules are resistant to management techniques, and serve as the major source of reinfestation the following year. From a management perspective, long-term control could be achieved by applying herbicides in the early spring when curlyleaf pondweed plants are young, and prior to new turion formation (Netherland et al. 2000, Poovey et al. 2002, Woolf and Madsen 2003).

Fluridone (1-methyl-3-phenyl-5-[3-(trifluromethyl)phenyl]-4(1H)pyridinone) is a slow-acting systemic aquatic herbicide that is applied in the form of an aqueous suspension or as a granular formulation. Once the herbicide is absorbed by the plant leaves and stems, fluridone interrupts the carotenoid biosynthetic pathway in newly developing tissue; carotenoid pigments protect the chlorophyll molecule from photooxidation. Results from previous small-scale studies using fluridone against the submersed invasives Eurasian watermilfoil (Myriophyllum spicatum L.) and hydrilla (Hydrilla verticillata (L.f.) Royle) have demonstrated that effective aquatic

plant control is dependent upon the length of time plants remain exposed to given herbicide concentrations (Netherland et al. 1993; Netherland and Getsinger 1995a, 1995b). These concentration/ exposure time studies have proven invaluable in the successful use of fluridone to control these weeds in the field (Getsinger and Netherland 1997, Getsinger et al. 2001). Optimum fluridone efficacy is attained with whole-lake treatments, or very large treatment blocks ( $>25$ ha or $>62$ acres). Whole-lake treatments have been successful in U.S. water bodies ranging from 4 to 15,000 ha (10 to 
37,100 acres). Plants susceptible to fluridone die and decompose slowly, with $>90 \%$ control achieved in the year of treatment. Rates from 5 to $8 \mu \mathrm{g}$ ai $\mathrm{L}^{-1}(\mathrm{ppb})$ of fluridone have proven selective for Eurasian watermilfoil, with minimal injury to many non-target plants (Netherland et al. 1997, Madsen et al. 2002), and can often provide more than one season of Eurasian watermilfoil control.

Curlyleaf pondweed is noted as being susceptible to fluridone on the product labels, and while Smith and Pullman (1997) reported it as susceptible following posttreatment field surveys in Michigan, published literature on the recommended use rates and timing for efficacy of fluridone against curlyleaf pondweed is sparse. Current whole-lake fluridone strategies call for fall or early spring fluridone applications at rates ranging from 5 to $15 \mu \mathrm{g}$ ai $\mathrm{L}^{-1}$. Unlike Eurasian watermilfoil, curlyleaf pondweed relies on turion production as a major means of annual reinfestation. Longterm management strategies must take into account the prevention of new turion formation as well as measures to exhaust the existing population of quiescent turions that are viable in the sediment. Prevention of rapid reinfestation from the dormant turion bank may require sustained management efforts for more than one season. Such has been the case with whole-lake spring treatments of endothall (Skogerboe et al. 2006).

In some instances, the frequency of curlyleaf pondweed has increased one year post-treatment when Eurasian watermilfoil was successfully removed in Michigan lakes that received whole-lake treatments of $5 \mu \mathrm{g}$ ai $\mathrm{L}^{-1}$ fluridone (Getsinger et al. 2002, Madsen et al. 2002). While these and other field observations have questioned the effectiveness of using fluridone for curlyleaf pondweed management, it should be noted that these treatments were conducted in mid-May after curlyleaf pondweed turion formation had already begun. The combination of continued turion production in the spring and the loss of Eurasian watermilfoil as a competitor the following season may influence the ability of curlyleaf pondweed to proliferate the year following May and J une fluridone applications.

In some aquatic systems where curlyleaf pondweed has formed dense monocultures, the rapid and complete loss of all vegetation following whole-lake control measures could be quite disruptive to the water quality and fishery of the lake. The ability to prevent biomass from growing to nuisance levels, while preventing turion production could represent a new strategy in controlling the growth and reinfestation potential of curlyleaf 
pondweed while minimizing risk to water quality and fish communities. Rates of fluridone that provide growth regulation and reduction of turion formation versus phytotoxicity against curlyleaf pondweed would fit into this new strategy. In conjunction with growth regulation, prevention of new turion formation is key to any long-term management program for curlyleaf pondweed. Field operational treatments that provide significant growth reduction of curlyleaf pondweed (but not complete control) during the year of treatment may be fully acceptable to managers and end-users of an infested lake. Furthermore, this strategy would be an optimal scenario for fluridone selectivity. The combination of early timing and low use rates would likely prove to be non-injurious to many of the desirable native submersed plant species.

\section{Objectives}

The overall objective of this research was to investigate the impact of fluridone on the growth and reproduction of curlyleaf pondweed under cool water temperatures and short day lengths representing an early spring application. The authors evaluated: a) low herbicide doses to reduce plant growth and prevent turion formation during the year of treatment;

b) applications that simulated field degradation versus applications that used booster treatments to maintain a herbicide dose for a specific exposure period; c) the influence of plant growth stage on fluridone efficacy. 


\section{Greenhouse Experiment I}

\section{Methods and Materials}

Greenhouse Experiment I was conducted at the US Army Engineer Research and Development Center, Lewisville Aquatic Ecosystem Research Facility (LAERF), Lewisville, TX. This study evaluated low fluridone doses that ranged from 0.5 to $6 \mu \mathrm{g}$ ai $\mathrm{L}^{-1}$ using exposure times that mimicked field degradation with plants of different plant heights (short, medium, and tall), but the same age.

Five 1200-L fiberglass tanks were used as temperature-regulated water baths. Eight vertical polypropylene aquaria $(70 \mathrm{~L}$ ) were placed into each fiberglass tank. While the large tanks served to regulate the water temperature, the polypropylene tanks served as independent experimental units. Water temperatures were maintained to specification by continuous recirculation through a Remcor ${ }^{\circledR}$ chiller (Remcor Products Company, Glendale Heights, IL). Lighting over each fiberglass tank was provided by 400-watt, wide-spectrum metal halide bulbs. Water temperatures and light were adjusted throughout the study to simulate spring field conditions in Minnesota to induce turion formation (Table 1).

Table 1. Daylength and water temperature adjustments to simulate spring field conditions in southern Minnesota.

\begin{tabular}{|l|l|l|}
\hline Time Frame & $\begin{array}{l}\text { Daylength } \\
\text { L:D }\end{array}$ & $\begin{array}{l}\text { Water temp } \\
{ }^{\circ} \mathrm{C}\end{array}$ \\
\hline Weeks $1-4$ & $12: 12$ & 14 \\
\hline Weeks $5+6$ & $12: 12$ & 16 \\
\hline Weeks $7+8$ & $13: 11$ & 16 \\
\hline Weeks $9+10$ & $14: 10$ & 18 \\
\hline Weeks $11+12$ & $14: 10$ & 20 \\
\hline
\end{tabular}

Water temperatures were monitored continuously with an Optic Stowaway Temperature Probe (Onset Computer Corp., Bourne, MA) in the water bath tanks. Light was measured over two aquaria in each water bath tank at $1300 \mathrm{~h}$ at 28 and 56 days after treatment (DAT), respectively, with a LiCor LI-250A light meter (Lincoln, NE). Conductivity and $\mathrm{pH}$ were 
measured in each aquarium biweekly with a YSI 556 multi-parameter probe (Yellow Springs, $\mathrm{OH}$ ).

Curlyleaf pondweed turions were obtained from Cedar Lake, MN. Three turions were planted in plastic containers $(820 \mathrm{~mL})$ filled with sediment amended with $2.5 \mathrm{~g} \mathrm{~L}^{-1}$ Osmocote ${ }^{\circledR}$ fertilizer (18-6-12). Mean turion weight $( \pm 1 \mathrm{SE}, \mathrm{n}=10$ ) was $0.61 \pm 0.04 \mathrm{~g}$. Sediment was capped with a 1 -cm layer of coarse-grit sand to prevent suspension of sediment particles in the water column. Three containers were placed in each aquarium. Turions sprouted after 14 days. Plants then grew for approximately 21 days, at which time they were divided into three height classes: short, medium, and tall. Each aquarium contained one container of each height class before herbicide treatment. Mean heights ( $\pm 1 \mathrm{SE}, \mathrm{n}=33$ ) were $12.6 \pm 0.64,22.0 \pm 0.48$, and $36.7 \pm 1.47 \mathrm{~cm}$ for short, medium and tall plants, respectively.

Curlyleaf pondweed plants were dosed with a liquid formulation of fluridone (Sonar ${ }^{\circledR}$ A.S., SePRO Corp, Carmel, IN) at concentrations between 0 and 6 ug ai $\mathrm{L}^{-1}$ (Table 2). In order to simulate various concentration and exposure scenarios, tanks were flushed at 28 and 56 days and new fluridone target rates were applied. Tanks were flushed by placing a water supply hose in the bottom of a tank and filling with untreated water for 30 minutes. For example, a treatment of "3-2-1" was an initial fluridone dose of $3 \mu \mathrm{g}$ ai L $\mathrm{L}^{-1}$ for a 28-day exposure, followed by a complete flushing, and a second dose of $2 \mu \mathrm{g}$ ai $\mathrm{L}^{-1}$ for a 28-day exposure, followed by a complete flushing, and a third dose of $1 \mu \mathrm{g} \mathrm{ai} \mathrm{L}^{-1}$ for a 12 -day exposure. Treatment strategies were designed to evaluate potential differences between the relatively stable concentrations that can be maintained via bump applications versus a steadily declining concentration that follows a single application. The study terminated after 70 days.

Water samples were collected in 30-ml, high-density polypropylene amber bottles from all aquaria at 2, 28, 30, 56, 58, and 70 DAT. These samples were analyzed by SePRO Corp. (Carmel, IN) using an enzyme-linked immunoassay (ELISA) to quantify actual concentrations and to monitor herbicide degradation (Netherland et al 2002). 
Table 2. Treatments of initial and re-applications of fluridone ( $\mu \mathrm{g}$ ai $\mathrm{L}^{-1}$ ) during the curlyleaf pondweed study, based on actual herbicide residue data.

\begin{tabular}{|l|l|l|}
\hline $\begin{array}{l}\text { Initial } \\
\text { Application } \\
\mu g \text { ai L-1 }\end{array}$ & $\begin{array}{l}\text { Application } \\
28 \mathrm{~d} \\
\mu g \text { ai L-1 }\end{array}$ & $\begin{array}{l}\text { Application } \\
56 \mathrm{~d} \\
\mu \mathrm{g} \text { ai L-1 }\end{array}$ \\
\hline 0 & 0 & 0 \\
\hline 0.5 & 0.5 & 0.5 \\
\hline 1 & 1 & 0.5 \\
\hline 1 & 1 & 1 \\
\hline 2 & 2 & 1 \\
\hline 3 & 1 & 0.5 \\
\hline 3 & 2 & 1 \\
\hline 3 & 2 & 3 \\
\hline 4 & 1 & 0.5 \\
\hline 4 & 2 & 1 \\
\hline 6 & 3 & 6 \\
\hline
\end{tabular}

Herbicide efficacy was assessed by measuring plant tissue pigment concentrations, shoot growth, root growth, and turion production. Tissue samples from plant shoot apices were taken at 28 and 56 DAT and analyzed for the pigments phytoene and $\beta$-carotene after Sprecher et al. (1998) to determine plant injury to herbicide uptake. Shoot lengths were measured every 14 days to determine plant growth over the course of the study. Shoot and root biomass were harvested 70 DAT. Shoots were cut at the sediment surface, dried at $70^{\circ} \mathrm{C}$ for $48 \mathrm{hr}$, and weighed to obtain a biomass estimate for each replicate. Roots were collected, washed, dried at $70^{\circ} \mathrm{C}$ for $48 \mathrm{hr}$, and weighed to obtain a biomass estimate for each replicate.

Turions were collected and counted from each plant at 70 DAT. If turions had dropped to the bottom of the aquaria, these were collected from each aquarium. All turions were refrigerated at $4{ }^{\circ} \mathrm{C}$ for 7-10 days, then counted. Sprouting tests were conducted to determine turion viability. Turions were placed in petri dishes filled with distilled water. Petri dishes were placed in an environmental growth chamber at $22 \pm 2^{\circ} \mathrm{C}$, a light intensity of $575 \pm 50 \mu \mathrm{mol} \mathrm{m}^{-2} \mathrm{sec}^{-1}$, and light:dark cycle of 14:10 for 21 days. Sprouted turions were counted and removed. Unsprouted turions were re-refrigerated for 10 days, then placed in an environmental growth chamber. After 14 days, sprouted turions were counted and percent of sprouted turions calculated. 
There were three replicates for each herbicide treatment. Shoot and root biomass were analyzed using a two-way analysis of variance (ANOVA) to determine plant height and herbicide effects. Root biomass was squareroot transformed to satisfy assumptions of normality and equal variance. If effects were significant at $\mathrm{p} \leq 0.05$, means were separated using the Student-Newman-Keuls Method (S-N-K).

\section{Results and Discussion}

Water temperatures in the aquaria were $16^{\circ} \mathrm{C}$ at the time of initial treatment $0830 \mathrm{~h}$ on $28 \mathrm{~J} \mathrm{uly} 04$. Temperatures rose to $18^{\circ} \mathrm{C}$ by $1330 \mathrm{hr}$, then decreased to $16^{\circ} \mathrm{C}$ again the following morning. This diurnal temperature fluctuation occurred throughout the study (Figure 1). Light above the aquaria ranged from $542 \pm 25.3$ to $641 \pm 25.3 \mu \mathrm{mol} \mathrm{m}^{-2} \mathrm{sec}^{-1}$ during the study. Mean conductivity ranged from $0.236 \pm 0.004$ to 0.328 $\pm 0.003 \mathrm{mS} \mathrm{cm}^{-1}$ and the mean $\mathrm{pH}$ ranged from $8.2 \pm 0.09$ to $8.9 \pm 0.14$.

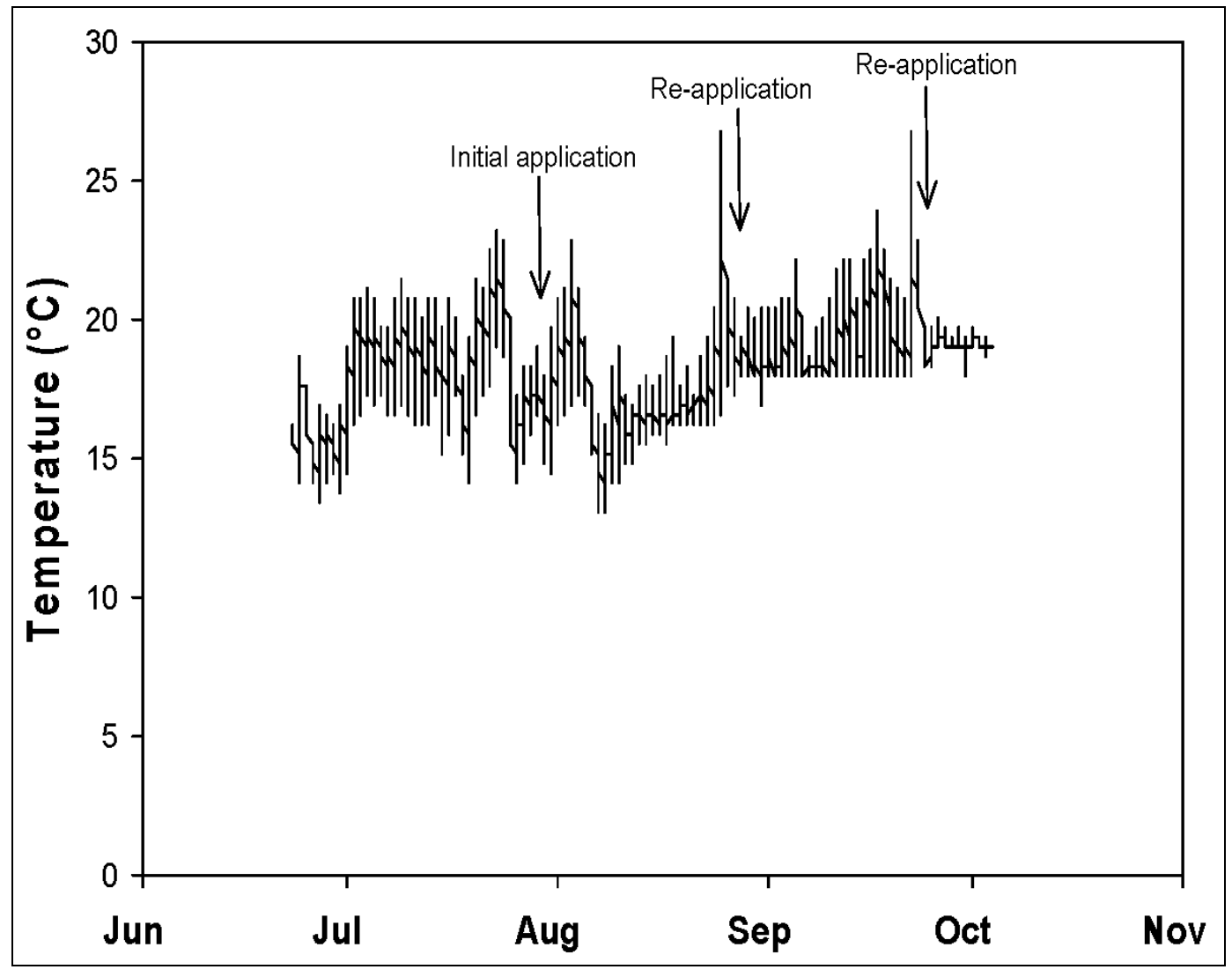

Figure 1. Temperatures taken in greenhouse water bath tanks. 


\section{Fluridone Residues}

Results from the fluridone residue analyses are shown in Table 3. Residues did not substantially decrease from 2 to 28 DAT, 30 to 56 DAT, or 58 to 70 DAT, indicating that herbicide degradation during testing was minimal; therefore, plants were subject to a nearly constant herbicide concentration during the various treatment intervals.

Table 3. Aqueous fluridone concentrations in aquaria at $2,28,30,56,58$, and 70 days after treatment (DAT).

\begin{tabular}{|l|l|l|l|l|l|l|}
\hline \multirow{2}{*}{$\begin{array}{l}\text { Nominal treatment } \\
\text { concentrations }\end{array}$} & \multicolumn{7}{|c|}{ Herbicide Concentrations $\mu g$ ai L-1 } \\
\cline { 2 - 8 } & 2 DAT & 28 DAT & 30 DAT & 56 DAT & 58 DAT & 70 DAT \\
\hline $0.5-0.5-0.5$ & 0.65 & $<11$ & 0.6 & $<1$ & $<1$ & $<1$ \\
\hline $1-1-0.5$ & 1.3 & 1.4 & 1.3 & 1.1 & 1.2 & $<1$ \\
\hline $1-1-1$ & 1.2 & 1.4 & 1.1 & 1.2 & 1.4 & 1 \\
\hline $2-2-1$ & 2.2 & 1.9 & 1.45 & 2.1 & 1.4 & \\
\hline $3-1-0.5$ & 3.1 & 2.6 & 1.6 & 1.3 & $<1$ & $<1$ \\
\hline $3-2-1$ & 3.2 & 2.4 & 2.5 & 2.3 & 1.1 & 1.2 \\
\hline $3-2-3$ & 2.9 & 2.9 & 2.5 & 1.9 & 2.6 & 3 \\
\hline $4-1-0.5$ & 3.8 & 3.7 & 1.2 & 1.1 & $<1$ & $<1$ \\
\hline $4-2-1$ & 4 & 3.4 & 2.7 & 2.1 & 1.7 & 1.1 \\
\hline $6-3-6$ & 5.7 & 6.2 & 3.6 & 3.3 & 5.3 & 6.2 \\
\hline 1 Concentrations of $<1=$ readings below $0.5 \mu g$ ai L-1. & & & \\
\hline
\end{tabular}

\section{Plant Growth}

Growth of curlyleaf pondweed after fluridone treatment was influenced by the plant height at the time of herbicide application. Although root biomass was not influenced by herbicide treatment or plant height, shoot biomass differed between short, medium, and tall plants with a significant height by treatment interaction $(\mathrm{F}=2.050, \mathrm{p}=0.016)$. Tall plants generated the greatest shoot biomass and turions (Figure 2) with more shoots reaching the water surface (Figure 3) than either medium (Figures 4 and 5) or short plants (Figures 6 and 7). 


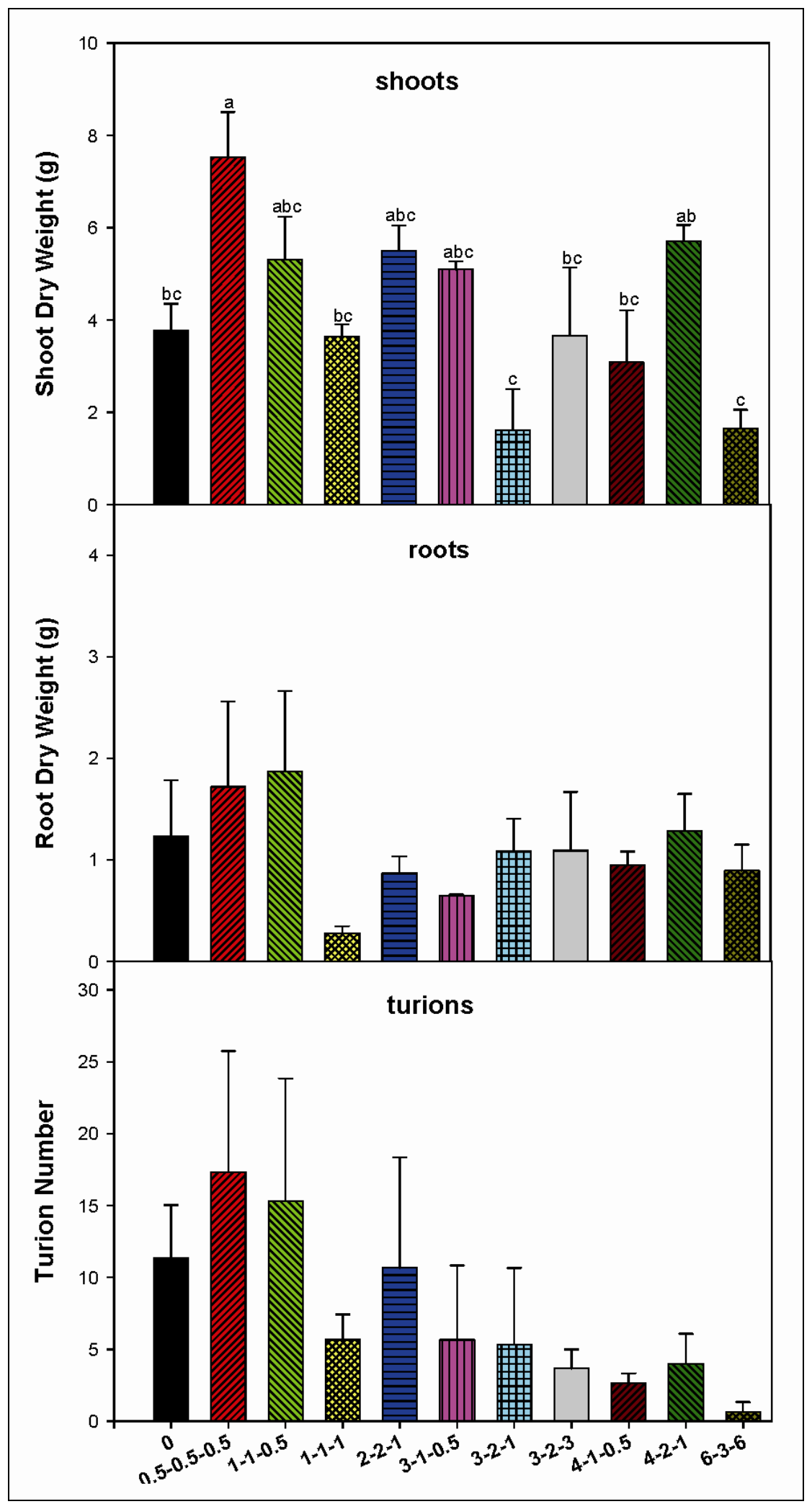

Figure 2. Shoot biomass (g), root biomass (g) and number of turions (mean $\pm 1 \mathrm{SE}$ ) collected from tall curlyleaf pondweed plants at 70 days after fluridone application. Treatments with the same letters are statistically similar $(\mathrm{S}-\mathrm{N}-\mathrm{K}, \mathrm{p}<0.05)$. 


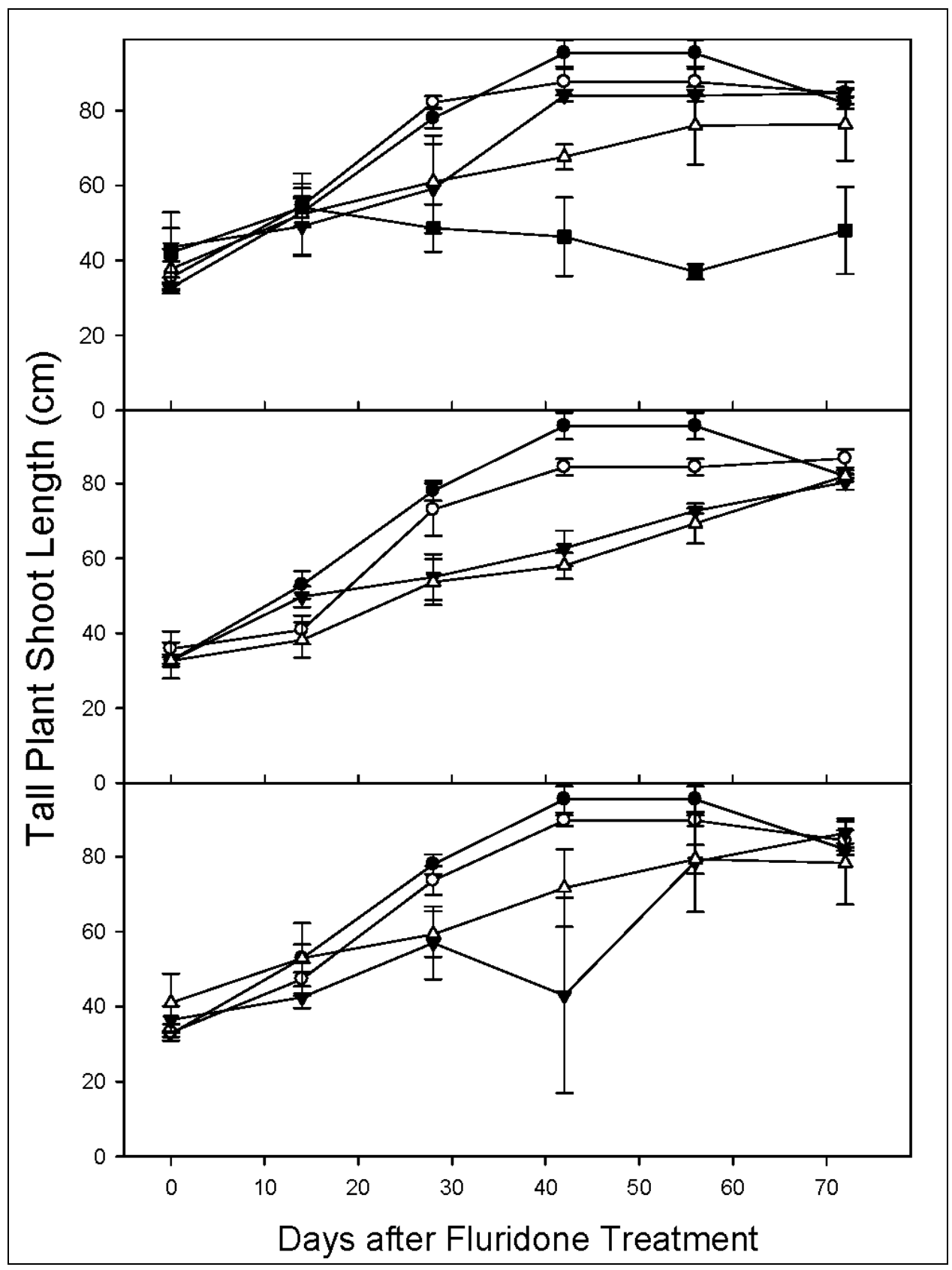

Figure 3. Shoot length (mean $\pm 1 \mathrm{SE} \mathrm{cm}$ ) of tall curlyleaf pondweed plants after fluridone application. 


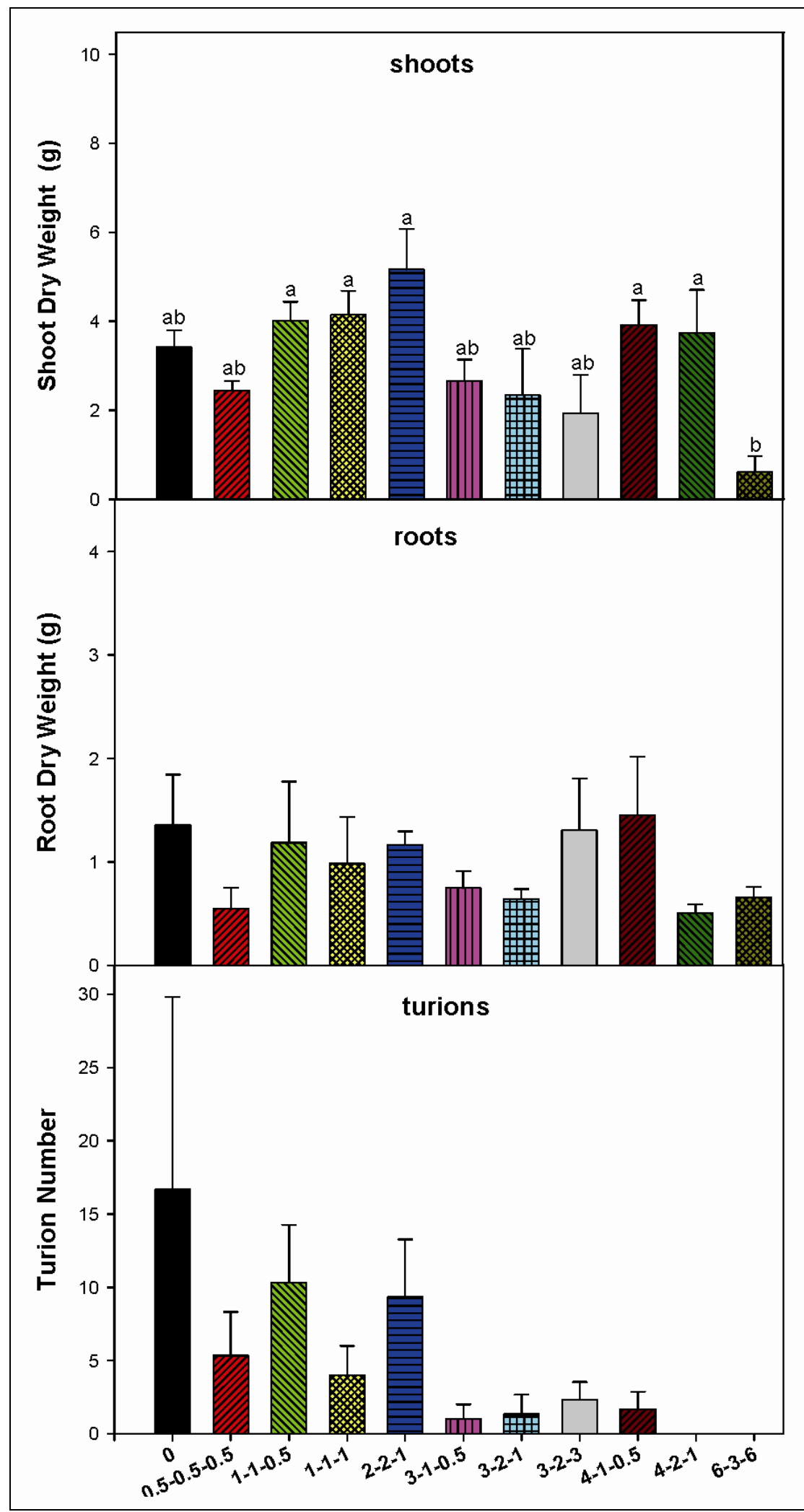

Figure 4. Shoot biomass (g), root biomass (g) and number of turions (mean $\pm 1 \mathrm{SE}$ ) collected from medium curlyleaf pondweed plants at 70 days after fluridone application. Treatments with the same letters are statistically similar $(\mathrm{S}-\mathrm{N}-\mathrm{K}, \mathrm{p}<0.05)$. 


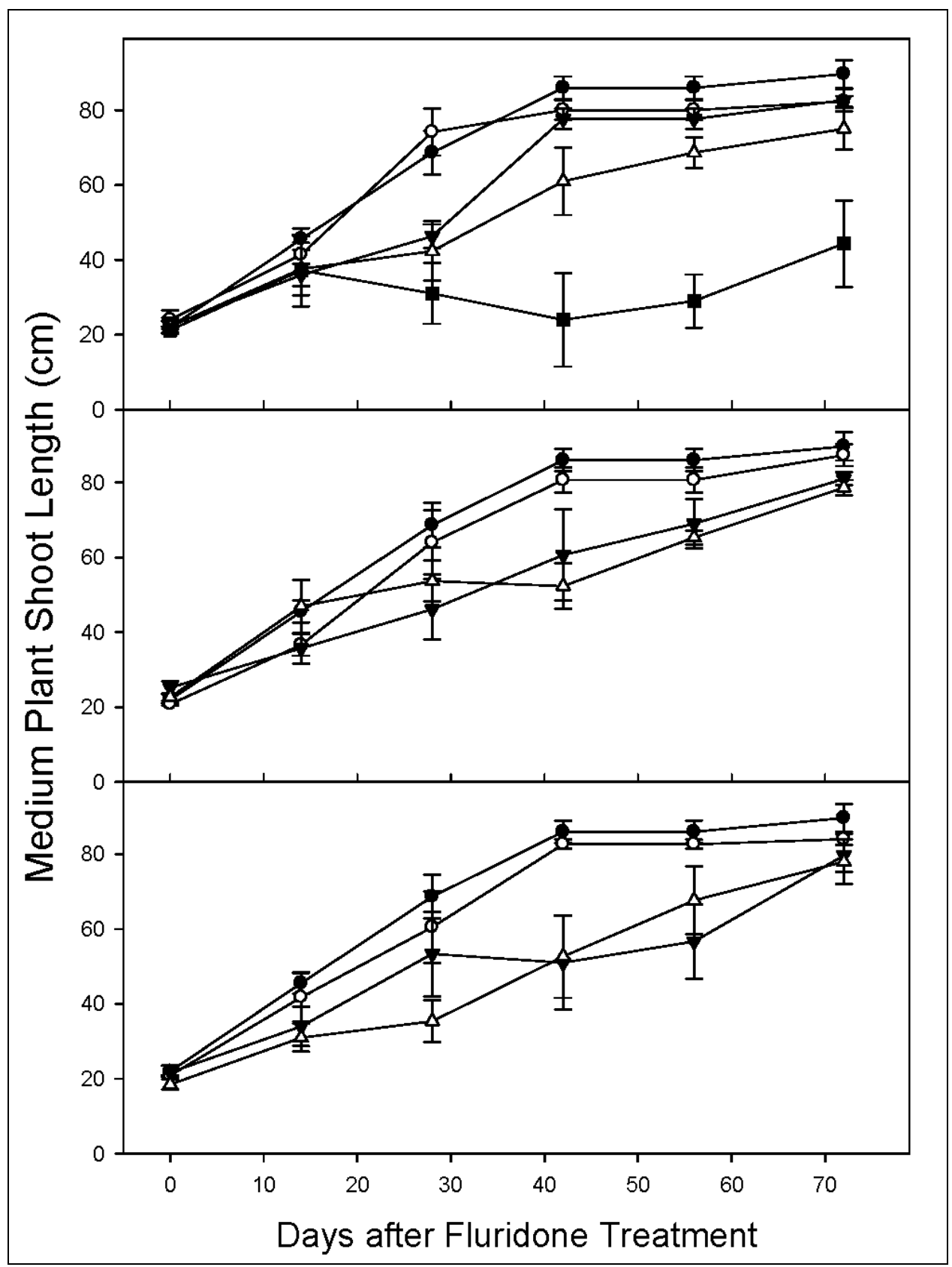

Figure 5 . Shoot length (mean $\pm 1 \mathrm{SE} \mathrm{cm}$ ) of medium curlyleaf pondweed plants after fluridone application. 


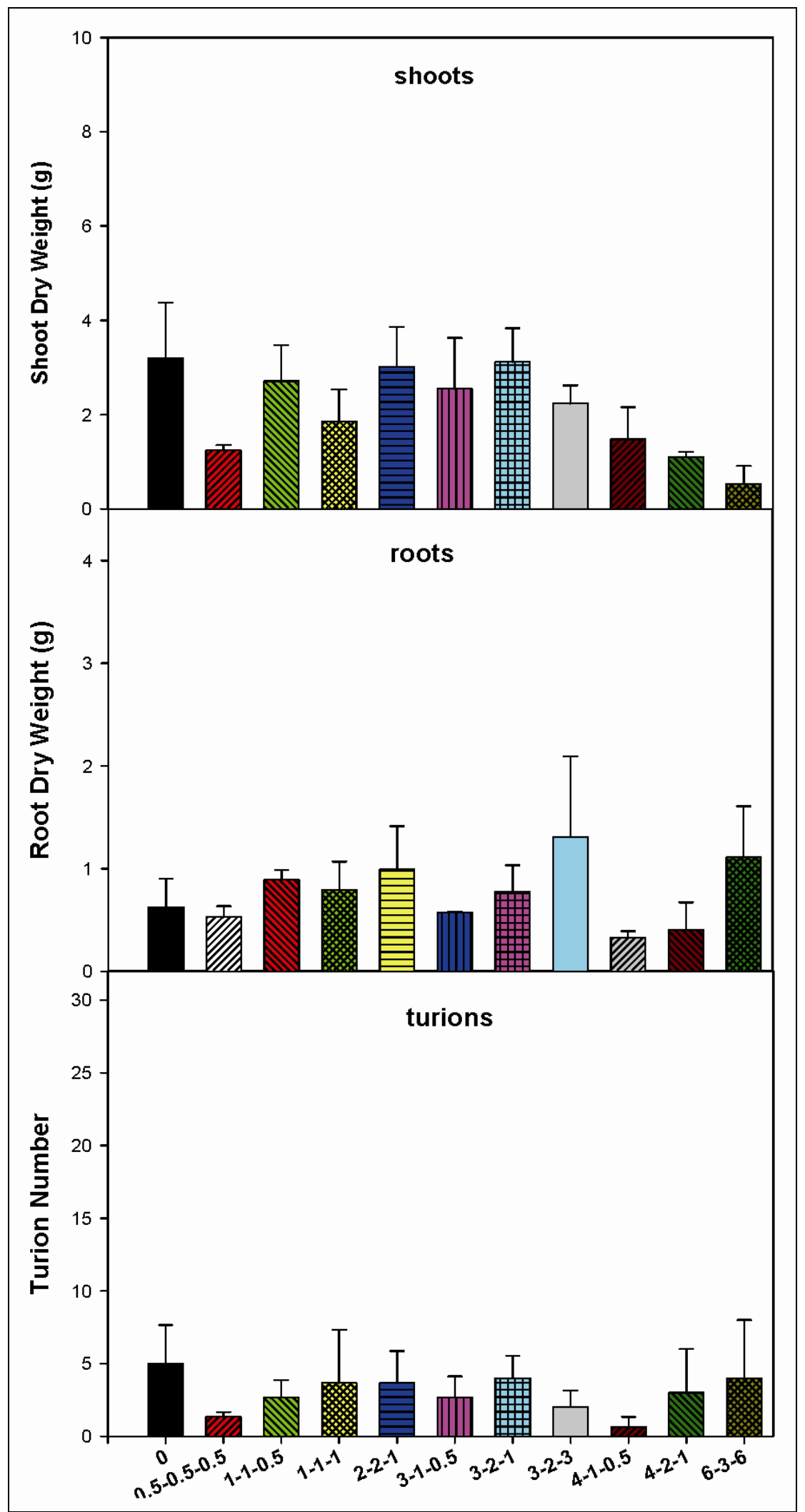

Figure 6. Shoot biomass (g), root biomass (g) and number of turions (mean $\pm 1 \mathrm{SE}$ ) collected from short curlyleaf pondweed plants at 70 days after fluridone application. 


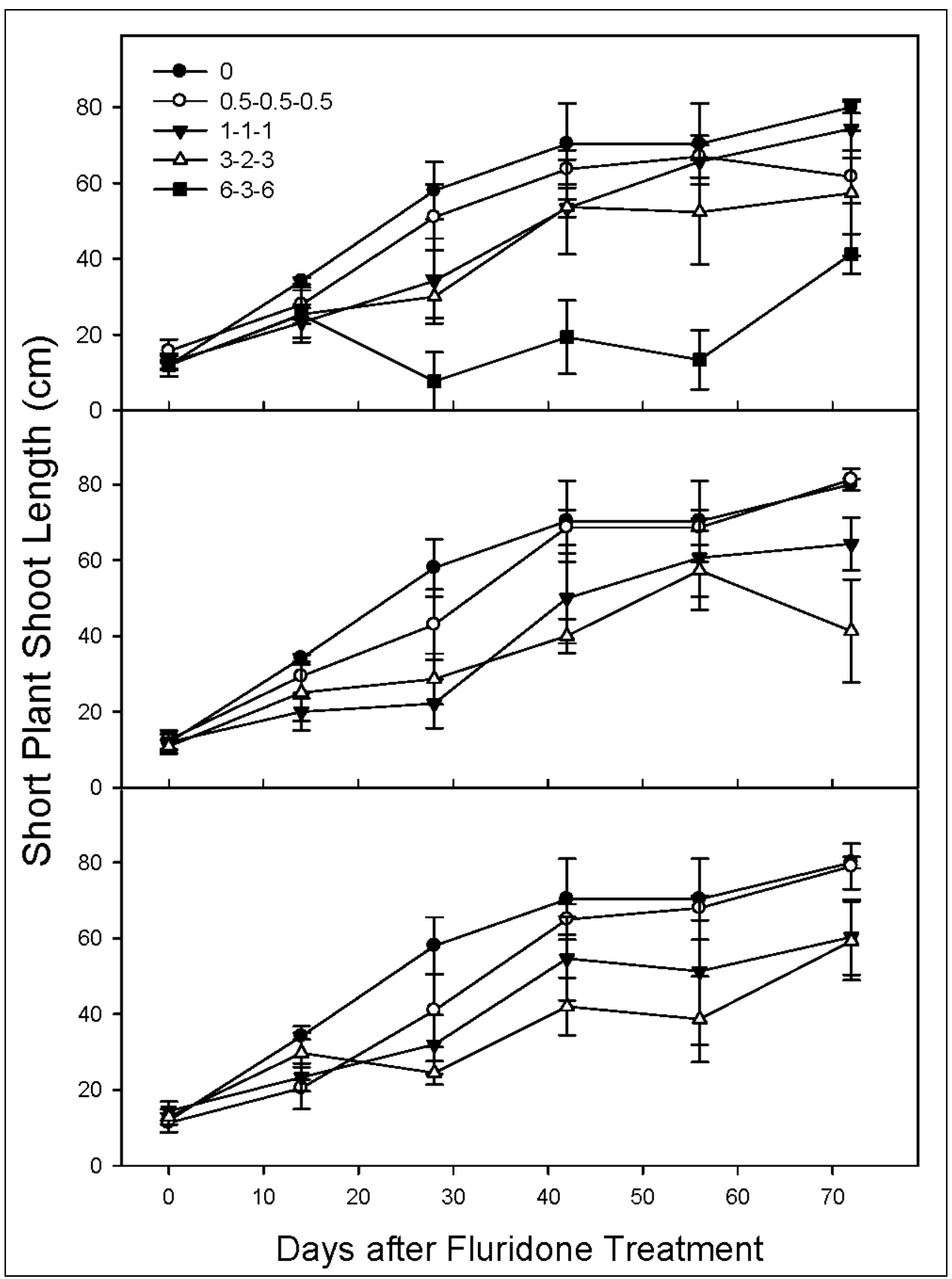

Figure 7. Shoot length (mean $\pm 1 \mathrm{SE} \mathrm{cm}$ ) of short curlyleaf pondweed plants after fluridone application.

Tall plants dosed with 0.5-0.5-0.5 $\mu \mathrm{g}$ ai $\mathrm{L}^{-1}$ fluridone produced more shoots than the untreated references (Figure 2). All other treatments for tall plants were similar to the untreated references, even the 6-3-6 $\mu \mathrm{g}$ ai $\mathrm{L}^{-1}$ treatment, which was the only treatment that appeared to stop growing after 28 days of herbicide exposure as indicated by the downward trend in plant height (Figure 3). 
Pigment concentrations showed that plants treated with 6-3-6 $\mu$ g ai L-1 exhibited typical symptoms of fluridone uptake: elevated levels of phytoene in the plant shoots at 28 and 56 DAT (Table 4). Levels of $\beta$-carotene showed that plants were declining at 28 DAT with concentrations below $10 \mu \mathrm{gg}$ $\mathrm{FW}^{-1}$; however, by $56 \mathrm{DAT}$, plants were rebounding with concentrations of $24.6 \pm 5.35 \mu \mathrm{g} \mathrm{FW}^{-1}$. A fluridone dose of $3 \mu \mathrm{g}_{\text {ai L }} \mathrm{L}^{-1}$ applied at $28 \mathrm{DAT}$ was sufficient to sustain herbicide injury and stop plant growth, but not kill the plant. Nonetheless, turions collected from the plant shoots at the end of the study indicate that this dose substantially reduced turion numbers for medium (Figure 4) and tall plants (Figure 2). A total of $12.0 \pm 5.29$ turions were collected for the 6-3-6 $\mu$ gai $\mathrm{L}^{-1}$ treatment at the end of the study compared to $102 \pm 36.8$ turions for the untreated reference (Table 5). It is clear that this treatment was effective in suppressing growth of curlyleaf pondweed and inhibiting turion production.

Table 4. Concentrations of phytoene and $\beta$-carotene (mean $\pm 1 \mathrm{SE} \mu \mathrm{g} g \mathrm{FW}^{-1}$ ) in curlyleaf pondweed shoots 28 and 56 days after treatment (DAT) of fluridone. Different letters within a column denote significant differences among treatments (S-N-K, $\mathrm{p} \leq 0.05)$.

\begin{tabular}{|c|c|c|c|c|}
\hline \multirow{2}{*}{$\begin{array}{l}\text { Treatment } \\
\mu \mathrm{g} \text { ai } \mathrm{L}^{-1}\end{array}$} & \multicolumn{2}{|c|}{$\begin{array}{l}\text { Phytoene } \\
\text { Lg g FW-1 }\end{array}$} & \multicolumn{2}{|c|}{$\begin{array}{l}\text { } \beta \text {-carotene } \\
\mu \mathrm{g} \mathrm{g} \mathrm{FW}-1\end{array}$} \\
\hline & 28 DAT & 56 DAT & 28 DAT & 56 DAT \\
\hline 0 & $28.0 \pm 2.04 \mathrm{~b}$ & $38.8 \pm 3.13 b$ & $41.5 \pm 1.90 \mathrm{a}$ & $63.2 \pm 8.09 a$ \\
\hline $0.5-0.5-0.5$ & $123 \pm 34.3 a$ & $117 \pm 14.6 \mathrm{a}$ & $33.9 \pm 1.98 a$ & $33.9 \pm 5.50 a$ \\
\hline 1-1-0.5 & $175 \pm 17.3 \mathrm{a}$ & $175 \pm 6.62 \mathrm{a}$ & $31.1 \pm 2.54 \mathrm{a}$ & $41.9 \pm 3.40 \mathrm{a}$ \\
\hline $1-1-1$ & $156 \pm 5.00 \mathrm{a}$ & $122 \pm 11.2 \mathrm{a}$ & $31.4 \pm 10.6 \mathrm{a}$ & $48.6 \pm 3.50 \mathrm{a}$ \\
\hline $2-2-1$ & $279 \pm 11.8$ a & $157 \pm 49.5 \mathrm{a}$ & $27.5 \pm 1.24 \mathrm{a}$ & $37.0 \pm 14.5 \mathrm{a}$ \\
\hline 3-1-0.5 & $177 \pm 60.7$ a & $116 \pm 44.9 \mathrm{a}$ & $12.4 \pm 8.31 b$ & $43.0 \pm 8.79 a$ \\
\hline $3-2-1$ & $247 \pm 28.2 \mathrm{a}$ & $263 \pm 61.4 \mathrm{a}$ & $18.4 \pm 4.38 \mathrm{a}$ & $28.7 \pm 0.81 \mathrm{a}$ \\
\hline $3-2-3$ & $215 \pm 80.1 \mathrm{a}$ & $207 \pm 39.8$ a & $16.4 \pm 6.43 \mathrm{a}$ & $45.1 \pm 4.96 \mathrm{a}$ \\
\hline 4-1-0.5 & $183 \pm 47.0 \mathrm{a}$ & $152 \pm 5.00 \mathrm{a}$ & $15.2 \pm 5.66 \mathrm{a}$ & $46.4 \pm 9.21 \mathrm{a}$ \\
\hline $4-2-1$ & $189 \pm 32.6 \mathrm{a}$ & $236 \pm 21.2 \mathrm{a}$ & $8.36 \pm 1.64 b$ & $38.8 \pm 4.04 a$ \\
\hline $6-3-6$ & $191 \pm 31.2 \mathrm{a}$ & $206 \pm 14.1 \mathrm{a}$ & $7.18 \pm 2.62 b$ & $24.6 \pm 5.35 \mathrm{a}$ \\
\hline
\end{tabular}


Table 5. Number of axillary, stem, and hard stem turions (mean $\pm 1 \mathrm{SE}$ ) produced by curlyleaf pondweed plants after 70-day exposure to fluridone.

\begin{tabular}{|l|l|l|l|l|l|l|l|}
\hline \multirow{2}{*}{$\begin{array}{l}\text { Treatment } \\
\mu \text { g ai L-1 }\end{array}$} & \multicolumn{2}{|c|}{ Axillary Turions } & \multicolumn{2}{c|}{ Stem Turions } & \multirow{2}{*}{} & \multirow{2}{*}{ Total } \\
\cline { 2 - 7 } & Mature & Immature & Mature & Immature & Hard Stem & Sprouting \\
\hline 0 & $13.7 \pm 6.94$ & $36.0 \pm 11.1$ & $20.0 \pm 7.51$ & $27.7 \pm 20.2$ & $5.00 \pm 4.04$ & $102 \pm 36.8$ & $64.5 \pm 26.5$ \\
\hline $0.5-0.5-0.5$ & $9.67 \pm 1.45$ & $22.3 \pm 2.91$ & $23.0 \pm 9.71$ & $18.0 \pm 6.24$ & $5.67 \pm 4.26$ & $78.7 \pm 18.1$ & $58.9 \pm 14.2$ \\
\hline $1-1-0.5$ & $22.3 \pm 12.2$ & $21.3 \pm 8.17$ & $27.0 \pm 14.7$ & $16.7 \pm 6.69$ & $11.3 \pm 9.84$ & $98.7 \pm 39.3$ & $46.9 \pm 15.7$ \\
\hline $1-1-1$ & $3.00 \pm 2.52$ & $25.0 \pm 6.66$ & $21.7 \pm 16.5$ & $45.0 \pm 33.7$ & 0 & $94.7 \pm 58.7$ & $44.0 \pm 23.5$ \\
\hline $2-2-1$ & $11.3 \pm 2.03$ & $22.7 \pm 7.69$ & $9.00 \pm 5.57$ & $45.0 \pm 28.7$ & $2.33 \pm 0.33$ & $90.3 \pm 31.9$ & $78.9 \pm 8.04$ \\
\hline $3-1-0.5$ & $5.67 \pm 5.18$ & $7.33 \pm 4.10$ & $12.0 \pm 9.02$ & $7.00 \pm 4.04$ & 0 & $32.0 \pm 22.0$ & $43.2 \pm 3.42$ \\
\hline $3-2-1$ & $6.67 \pm 4.81$ & $6.33 \pm 3.53$ & $3.33 \pm 3.33$ & $4.33 \pm 3.38$ & $0.67 \pm 0.67$ & $21.3 \pm 15.6$ & $47.5 \pm 24.2$ \\
\hline $3-2-3$ & $7.33 \pm 5.90$ & $13.0 \pm 6.24$ & $2.33 \pm 1.45$ & $7.00 \pm 7.00$ & 0 & $29.7 \pm 13.4$ & $48.6 \pm 27.7$ \\
\hline $4-1-0.5$ & $4.00 \pm 2.08$ & $7.00 \pm 3.51$ & $3.67 \pm 1.20$ & $3.33 \pm 0.88$ & $0.33 \pm 0.33$ & $18.3 \pm 5.81$ & $60.4 \pm 30.3$ \\
\hline $4-2-1$ & $1.67 \pm 0.88$ & $10.3 \pm 6.74$ & $7.00 \pm 4.73$ & $5.67 \pm 4.70$ & $1.33 \pm 1.33$ & $26.0 \pm 17.5$ & $49.6 \pm 27.2$ \\
\hline $6-3-6$ & $0.33 \pm 0.33$ & $1.67 \pm 1.20$ & $1.33 \pm 0.33$ & $8.33 \pm 4.33$ & $0.33 \pm 0.33$ & $12.0 \pm 5.29$ & $47.0 \pm 26.2$ \\
\hline
\end{tabular}

Results for fluridone treatments of 4-2-1 and 4-1-0.5 $\mu \mathrm{g}$ ai L-1 varied considerably among plants (Figures 2,4 , and 6 ). Shoot biomass from neither treatment was significantly different than the untreated reference regardless of plant height. Fluridone treatments of $4 \mu \mathrm{g}$ ai L $\mathrm{L}^{-1}$ followed by another $4 \mu \mathrm{g}$ ai $\mathrm{L}^{-1}$ application after 2 weeks have greatly reduced curlyleaf pondweed in Minnesota lakes for as long as 1 year after treatment (Crowell et al. 2004). Those treatments maintained herbicide concentrations between 3 and $4 \mu \mathrm{g}$ ai $\mathrm{L}^{-1}$ for over 70 days (Schutz and Eagle Lakes). In this study, plants were injured by a dose of $4 \mu \mathrm{g}$ ai $\mathrm{L}^{-1}$, evident by the low $\beta$-carotene levels at 28 DAT (Table 4); however, the drop in fluridone concentrations from $4 \mu \mathrm{g}$ ai $\mathrm{L}^{-1}$ to $2 \mu \mathrm{g}$ ai $\mathrm{L}^{-1}$ and $1 \mu \mathrm{g}$ ai $\mathrm{L}^{-1}$ was inadequate to sustain plant injury as $\beta$-carotene levels increased to levels comparable to the untreated reference by 56 DAT. Although plants continued to grow and accumulate biomass through the study as demonstrated by the upward trend in the plant shoot lengths (Figures 3, 5, and 7), mean turion numbers for these treatments were $18.3 \pm 5.81$ and $26.0 \pm 17.5$ compared to $102 \pm 36.8$ turions for the untreated reference (Table 5). Fluridone treatments of 4-2-1 and 4-1-0.5 $\mu \mathrm{g}$ ai $\mathrm{L}^{-1}$ did not suppress curlyleaf pondweed growth in this study, but did inhibit turion production. Perhaps a fluridone concentration of $4 \mu \mathrm{g}$ ai $\mathrm{L}^{-1}$ for 56 days would decrease curlyleaf pondweed shoot biomass without completely killing the plant.

Like the treatments of 4-2-1 and 4-1-0.5 $\mu$ gai $\mathrm{L}^{-1}$, the treatments of 3-1-0.5, 3-2-1, and 3-2-3 $\mu$ g ai $\mathrm{L}^{-1}$ varied considerably among plants (Figures 2, 4, and 6). Plants were injured by a dose of $3 \mu \mathrm{g}$ ai $\mathrm{L}^{-1}$, evident by the low 
$\beta$-carotene levels at 28 DAT (Table 4); however, the drop in fluridone concentrations from $3 \mu \mathrm{g}$ ai $\mathrm{L}^{-1}$ to $2 \mu \mathrm{g}$ ai $\mathrm{L}^{-1}$ and $1 \mu \mathrm{g}$ ai $\mathrm{L}^{-1}$ was inadequate to sustain plant injury as $\beta$-carotene levels increased to levels comparable to the untreated reference by 56 DAT.

A dose of 3 at 56 DAT for the last 2 weeks of the study was enough to stop shoot elongation for all height classes (Figures 2, 5, and 7). Growth suppression from this treatment may have been greater if plants would have been exposed to $3 \mu \mathrm{g}$ ai $\mathrm{L}^{-1}$ for more than 2 weeks after 56 DAT or for more than 4 weeks after initial treatment. Nonetheless, mean turion numbers for these treatments ranged from $21.3 \pm 15.6$ to $32.0 \pm 22.0$ compared to $102 \pm 36.8$ turions for the untreated reference (Table 5). Again, like the 4-2-1 and 4-1-0.5 $\mu \mathrm{g}$ ai $\mathrm{L}^{-1}$ treatments, treatments with initial doses of $3 \mu \mathrm{g}$ ai $\mathrm{L}^{-1}$ fluridone did not completely suppress growth, but did greatly inhibit turion production of curlyleaf pondweed.

Treatments of $\leq 2 \mu \mathrm{g}$ ai L $\mathrm{L}^{-1}$ resulted in plant growth and turion production that was either similar or greater than the reference. It is unlikely that these very low doses of fluridone would have more of a negative impact on curlyleaf pondweed even if the exposure time had been extended beyond 70 days. Sprecher et al. (1998) reported that long-term exposures to $2 \mu \mathrm{g}$ ai $\mathrm{L}^{-1}$ produced characteristic pigment changes in sago pondweed (Stuckenia pectinata L.) and American pondweed (Potamogeton nodosus Poiret), but biomass reduction or deleterious effects on development did not occur.

\section{Turions}

Three kinds of curlyleaf pondweed turions were collected from the treatments: "stout, horny, denticulate" turions, "slender spicular" turions (described by Kunii 1989), and "hard stems" (described by Poovey et al. 2002). For the purpose of this report, the "stout, horny denticulate" turions will be "axillary turions" and the "slender spicular" turions will be "stem turions." Immature and mature turions were collected from both of these types (Table 5).

Although differences in turion number between treatments was not statistically significant $(\mathrm{F}=2.282, \mathrm{p}=0.051)$, there was a strong trend of decreasing turion numbers with increasing fluridone concentrations. Numbers of turions were greater in plants treated with fluridone doses of $\leq 2 \mu \mathrm{g}$ ai $\mathrm{L}^{-1}$ and less in plants treated with fluridone doses of $\geq 3 \mu \mathrm{g}$ ai $\mathrm{L}^{-1}$. 
Not surprisingly, stem turion formation was observed in all treatments by 28 DAT. Sastroutomo (1980) found that turions can be induced at water temperatures ranging from 13 to $24^{\circ} \mathrm{C}$ and a photoperiod 12:12. Chambers et al. (1985) reported that 30 days was the minimum response time of turion formation in curlyleaf pondweed under these conditions.

Immature axillary turions were observed at 56 DAT. Mature axillary turions were found floating in three aquaria at this time: the reference and treatments 1-1-0.5 and 2-2-1 $\mu$ gai $\mathrm{L}^{-1}$. By $70 \mathrm{DAT}$, all treatments produced mature axillary turions. Although short plants did not produce as many turions (Figure 6) as medium (Figure 4) and tall plants (Figure 2), it is important to note that turions were found on plant stems that were $>65 \mathrm{~cm}$ below the water surface on plants that would be considered "immature."

Sprouting of turions was similar among treatments $(\mathrm{F}=0.242, \mathrm{p}=0.988)$, with total percent sprouting of turions ranging from 43 to $78 \%$ (Table 5). Mature axillary and stem turions had the highest percentage of sprouting with $100 \%$ of turions sprouting from some treatments, including the 6-3-6 $\mu$ g ai $\mathrm{L}^{-1}$ treatment. Sprouting of immature axillary turions also was high with 39 to $93 \%$ of turions sprouting. Less than $50 \%$ of immature stem and hard stem turions sprouted. Lack of sprouting of immature stem turions may have been due to inadequate carbohydrate reserves. Lack of sprouting in hard stems may be due to the high light conditions in the ERDC Vicksburg growth chamber, as these turions are produced and found near the sediment. 


\section{Greenhouse Experiment II}

\section{Methods and Materials}

Greenhouse Experiment II was conducted at the LAERF, and focused on fluridone doses that ranged from 3 to $6 \mu \mathrm{g}$ ai $\mathrm{L}^{-1}$ with exposure times designed to mimic field booster applications, which provide relatively stable aqueous herbicide concentrations over a period of time. Plants in this study were treated at different times, and therefore, were different ages (young and mature).

Six 1200-L fiberglass tanks were used as temperature-regulated water baths. Eight vertical polypropylene aquaria $(70 \mathrm{~L}$ ) were placed into each fiberglass tank. While the large tanks served to regulate the water temperature, the polypropylene aquaria served as independent experimental units. Water temperatures were maintained in the large tanks by continuous recirculation through a Remcor ${ }^{\circledR}$ chiller (Remcor Products Company, Glendale Heights, IL). Lighting over each fiberglass tank was provided by 400 -watt, wide-spectrum metal halide bulbs. Water temperatures and light were adjusted throughout the study to simulate spring field conditions in Minnesota to induce turion formation (Table 6).

Table 6. Daylength and water temperature adjustments to simulate spring field conditions in southern Minnesota.

\begin{tabular}{|l|l|l|}
\hline Time Period & $\begin{array}{l}\text { Daylength } \\
\text { L:D }\end{array}$ & $\begin{array}{l}\text { Water temp } \\
{ }^{\circ} \mathrm{C}\end{array}$ \\
\hline Weeks 1-4 & $12: 12$ & 14 \\
\hline Weeks $3+4$ & $12: 12$ & 16 \\
\hline Weeks $5+6$ & $13: 11$ & 18 \\
\hline Weeks $7+8$ & $14: 10$ & 20 \\
\hline Weeks $9-12$ & $14: 10$ & 22 \\
\hline
\end{tabular}

Curlyleaf pondweed turions were obtained from Cedar Lake, MN and Eau Galle Reservoir, WI and stored in the dark at $4^{\circ} \mathrm{C}$ until ready for sprouting. Turions were sprouted in distilled water under fluorescent lighting that was $27 \mu \mathrm{mol} \mathrm{m}{ }^{-2} \mathrm{sec}^{-1}$, 14h:10h light:dark cycle, with air temperature of $23 \pm 1^{\circ} \mathrm{C}$ over a period of 4 weeks. Mean turion weight ( $\pm 1 \mathrm{SE}, \mathrm{n}=25$ ) was $0.46 \pm 0.04 \mathrm{~g}$. 
Two sprouted turions were planted in plastic containers $(820 \mathrm{~mL})$ filled with sediment amended with $2.5 \mathrm{~g} \mathrm{~L}^{-1}$ Osmocote ${ }^{\circledR}$ fertilizer (18-6-12). Each turion had shoots that were 2 to $7 \mathrm{~cm}$ in length. Sediment was capped with a 5-cm layer of coarse-grit sand to prevent suspension of sediment particles in the water column. Four containers were placed in each aquarium.

Plants were divided into two blocks based on plant height: young (shoot length $=11.0 \pm 0.65 \mathrm{~cm}, \mathrm{n}=21$ ) and mature (shoot length $=17.0 \pm 1.37 \mathrm{~cm}$, $\mathrm{n}=21)$. Four weeks after planting, the block of young plants were dosed with a liquid formulation of fluridone (Sonar ${ }^{\circledR}$ A.S., SePRO Corp, Carmel, IN), and eight weeks after planting, the block of mature plants were dosed with fluridone according to Table 7.

Table 7. Initial and re-applications of fluridone ( $\mu \mathrm{g}_{\mathrm{gi}} \mathrm{L}^{-1}$ ) to curlyleaf pondweed plants. Three applications were made to the Young Plant Block at 0,28 , and $56 \mathrm{~d}$, but only two applications were made to the Mature Plant Block at 0 and $28 \mathrm{~d}$.

\begin{tabular}{|l|l|l|}
\hline $\begin{array}{l}\text { Initial Application } \\
0 \mathrm{~d} \\
\mu g \text { ai L-1 }\end{array}$ & $\begin{array}{l}\text { Second Application } \\
\mathbf{2 8} \mathrm{d} \\
\mu \mathrm{g} \text { ai L-1 }\end{array}$ & $\begin{array}{l}\text { Third Application } \\
56 \mathrm{~d} \\
\mu_{\text {g ai L-1 }}\end{array}$ \\
\hline 0 & 0 & 0 \\
\hline 3 & 3 & 2 \\
\hline 4 & 2 & 2 \\
\hline 4 & 4 & 2 \\
\hline 5 & 2 & 2 \\
\hline 5 & 5 & 2 \\
\hline 6 & 2 & 2 \\
\hline
\end{tabular}

In order to simulate various concentration and exposure scenarios, treated water was flushed at 28 and 56 days from treatment aquaria and then flushed with untreated water before additional fluridone doses were applied. Aquaria were flushed by placing a water supply hose in the bottom of a tank and filling with untreated water for 30 minutes. For example, a treatment of "3-3-2" was an initial fluridone dose of $3 \mu \mathrm{g}$ ai L-1 for a 28-day exposure, followed by a complete flushing and a second dose of $3 \mu \mathrm{g}$ ai $\mathrm{L}^{-1}$ for a 28 -day exposure, followed by a complete flushing and a third dose of $2 \mu \mathrm{g}$ ai $\mathrm{L}^{-1}$ for a 16-day exposure providing a total exposure of 72 days. In the Young Plant Block, treatments followed the scenario described above; however, in the Mature Plant Block, plant senescence had started, preventing the third application of fluridone at 56 days after 
initial treatment (DAT). For both blocks, untreated references ( $0 \mu$ g ai $\left.\mathrm{L}^{-1}\right)$ compared plant growth in the absence of herbicide dosage.

Water samples were collected in 30-ml high-density polypropylene amber bottles from all aquaria 2 days after each dose and before flushing $(2,28$, 30, 56, 58 and 72 DAT). These samples were analyzed by SePRO Corp. (Carmel, IN) using an enzyme-linked immunoassay (ELISA) to quantify actual concentrations and to monitor herbicide degradation (Netherland et al. 2002).

Herbicide efficacy was assessed by measuring plant tissue pigment concentrations, shoot growth, and turion production. Tissue samples from plant shoot apices were taken at 28 and 56 DAT and analyzed for the pigments phytoene and $\beta$-carotene after Sprecher et al. (1998) to determine plant injury to herbicide uptake. Shoot lengths were measured by taking the length of most of the stems in each aquarium every 14 days to determine plant growth over the course of the study. Shoot biomass was harvested pretreatment, 28, 56, and 72 DAT for the young plant block, and pretreatment, 28, and 49 DAT for the mature plant block. Plant senescence prompted the harvest of all shoots in the Mature Plant Block at 49 DAT. Shoots were cut at the sediment surface, dried at $70^{\circ} \mathrm{C}$ for $48 \mathrm{hr}$, and weighed to obtain a biomass estimate for each replicate.

Axillary and stem turions (Kunii 1989) were collected from all treatments. Hard stems (as described by Poovey et al. 2002) were also harvested. Turions were refrigerated at $4{ }^{\circ} \mathrm{C}$ for 7 to 10 days, and then were counted. Sprouting tests were conducted to determine turion viability. Turions were placed in petri dishes filled with distilled water. Petri dishes were placed in an environmental growth chamber at $22 \pm 2^{\circ} \mathrm{C}$, a light intensity of $575 \pm 50 \mu \mathrm{mol} \mathrm{m}^{-2} \mathrm{sec}^{-1}$, and light:dark cycle of $14: 10$ for 21 days. Sprouted turions were counted and removed. Unsprouted turions were re-refrigerated for 10 days, then placed in an environmental growth chamber. After 14 days, sprouted turions were counted and percent of sprouted turions calculated.

There were three replicates for each treatment. All data were analyzed using a one-way analysis of variance (ANOVA) to test for herbicide effects. If the assumptions of normality and equal variance were not met, data were square-root transformed and reanalyzed. If herbicide effects were significant ( $\mathrm{p} \leq \mathrm{0.05}$ ), means were separated using the Student-NewmanKeuls method (S-N-K). 


\section{Results and Discussion}

Light above the aquaria ranged from $426 \pm 11.2$ to $529 \pm 13.9 \mu \mathrm{mol} \mathrm{m}^{-2} \mathrm{sec}^{-1}$ during the experiment. Mean conductivity ranged from $0.297 \pm 0.008$ to $0.335 \pm 0.006 \mathrm{mS} \mathrm{cm}^{-1}$ and the mean $\mathrm{pH}$ ranged from $8.0 \pm 0.03$ to $8.2 \pm 0.05$.

Water temperatures followed the pattern outlined in Table 6. Temperatures in treatment aquaria hovered at $14^{\circ} \mathrm{C}$ at planting in December, and at $16^{\circ} \mathrm{C}$ in J anuary, when the young plant block was first treated with fluridone (initial application; Figure 8). At herbicide re-applications, water

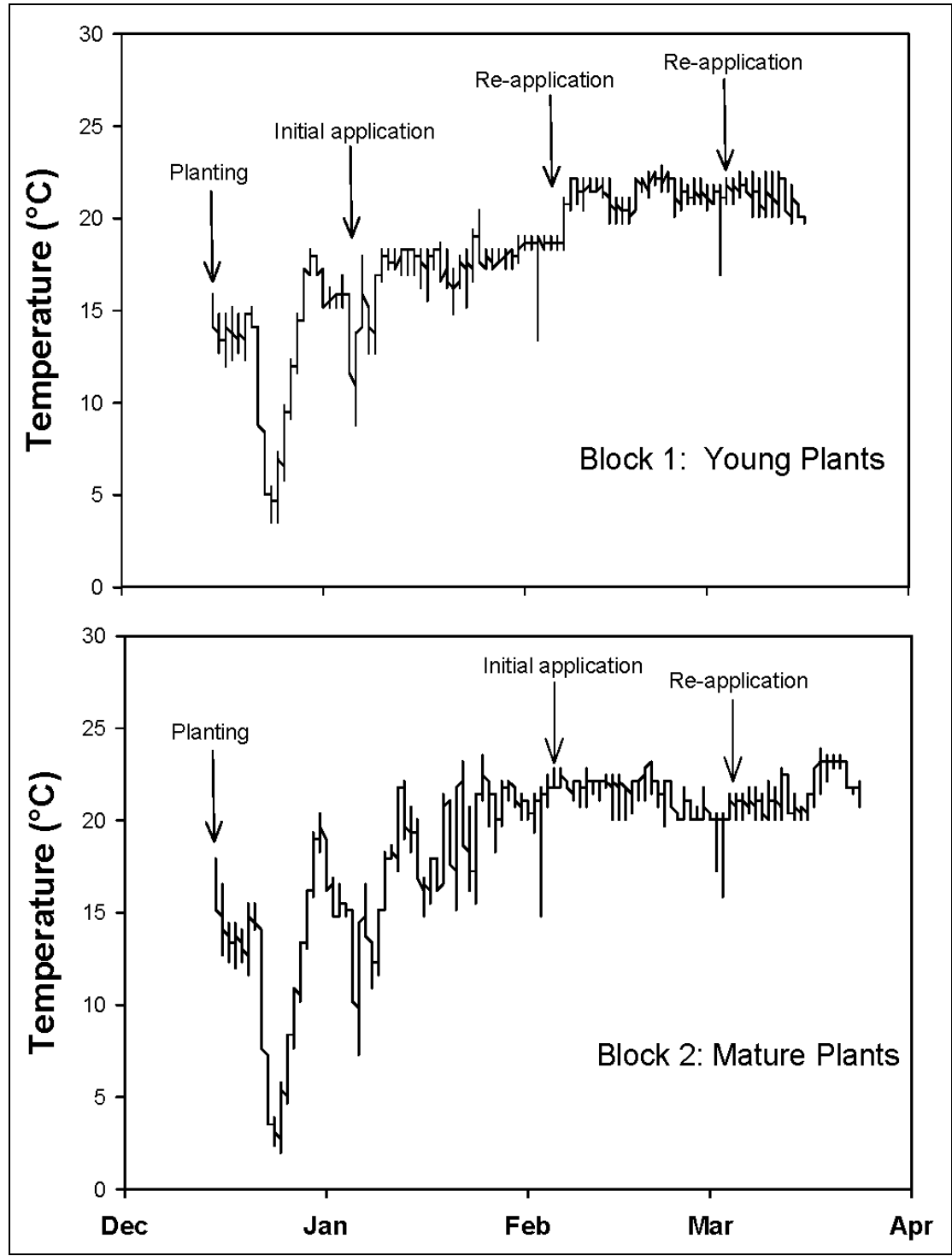

Figure 8. Temperatures in greenhouse water baths for Block 1: Young Plants (Tank 12) and Block 2: Mature Plants (Tank 18) from 15 December 2004 through 24 March 2005. 
temperatures were $18^{\circ} \mathrm{C}$ and $22^{\circ} \mathrm{C}$ in February and March, respectively. Water temperatures were slightly warmer in the mature plant block, with measurements of $23^{\circ} \mathrm{C}$ at initial application in February and $22^{\circ} \mathrm{C}$ at re-application in March (Figure 8). Temperatures increased to $\sim 25^{\circ} \mathrm{C}$ during the last week of the experiment.

\section{Fluridone Residues}

Results from the fluridone residue analyses are shown in Table 8. Aqueous fluridone residues were 6 to $20 \%$ above nominal concentrations, except for the 5-5 treatment, which had fluridone concentration $14 \%$ below nominal concentration. Aqueous herbicide concentrations were maintained throughout the study as there was little herbicide degradation between doses (data not shown).

\section{Young Plant Growth and Turion Production}

Shoot biomass for young curlyleaf pondweed plants is presented in Figure 9. By 56 DAT, there was a strong negative trend in shoot biomass as fluridone rates and exposure times increased with statistically significant differences between the 5-5-2 and the 3-3-2 treatments ( $\mathrm{F}=3.365, \mathrm{p}=0.032$ ). Although phytoene pigment concentrations were elevated, indicating herbicide uptake (Table 9), the 3-3-2 treatment did not affect shoot biomass at any time during the study (Figure 9).

Table 8. Aqueous fluridone concentrations in aquaria 2 days after initial, second and third doses (2, 30, and 58 DAT).

\begin{tabular}{|l|l|l|l|}
\hline $\begin{array}{l}\text { Nominal Treatment } \\
\text { Concentrations }\end{array}$ & \multicolumn{3}{|c|}{$\begin{array}{c}\text { Herbicide Concentrations } \\
\text { Mg ai L-1 }\end{array}$} \\
\hline$\mu g$ ai L-1 & 2 DAT & 30 DAT & 58 DAT \\
\hline \multicolumn{5}{|c|}{ Young Plant Block } \\
\hline $3-3-2$ & 3.5 & 2.5 & 2.9 \\
\hline $4-4-2$ & 4.3 & 4.3 & 2.4 \\
\hline $5-5-2$ & 5.7 & 5.7 & 2.7 \\
\hline $6-2-2$ & 6.5 & 2.7 & 2.9 \\
\hline \multicolumn{5}{|l|}{ Mature Plant Block } \\
\hline $3-3$ & 3.6 & 3.2 & $-a$ \\
\hline $4-4$ & 4.5 & 4.0 & - \\
\hline $5-5$ & 5.3 & 4.3 & - \\
\hline $6-2$ & 6.6 & 2.4 & - \\
\hline a Herbicide was not applied to Mature Plant Block at 56 DAT \\
\hline \multicolumn{5}{|l|}{} \\
\hline
\end{tabular}




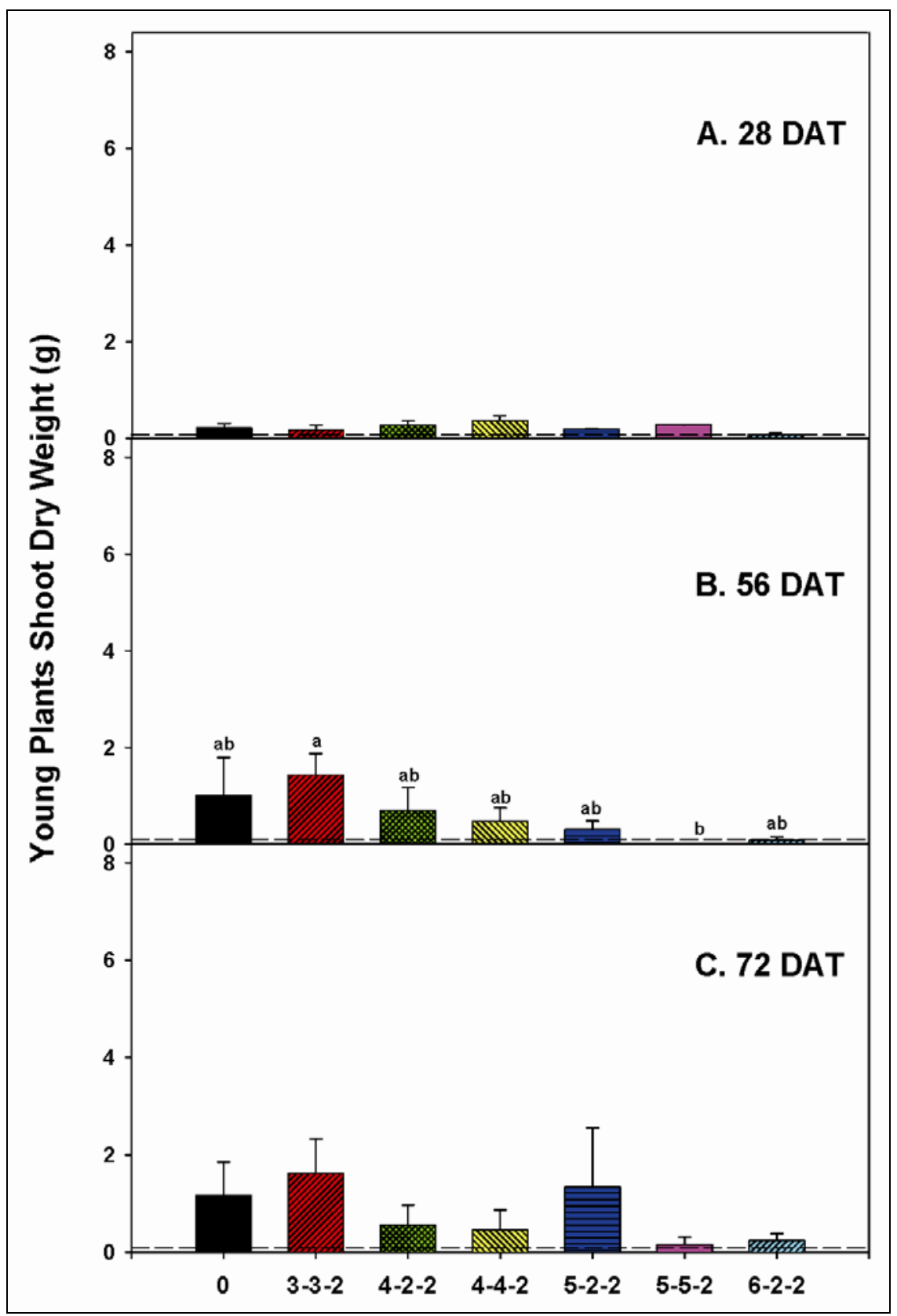

Figure 9. Mean ( $\pm 1 \mathrm{SE}$ ) shoot biomass (g) collected from young curlyleaf pondweed plants at A) $\mathbf{2 8}$ days after fluridone treatment (DAT), B) 56 DAT, and C) 72 DAT. Dashed horizontal line indicates biomass at the time of treatment. Treatments with different letters are significantly different ( $\mathrm{S}-\mathrm{N}-\mathrm{K}, \mathrm{p} \leq 0.05)$. 
Table 9. Mean ( $\pm 1 \mathrm{SE})$ concentrations of phytoene and $\beta$-carotene $\left(\mu \mathrm{g} \mathrm{FW}^{-1}\right)$ in curlyleaf pondweed shoots after exposure to fluridone. Samples were taken at 28 and 56 days after treatment (DAT) in young plants and at 28 and 49 DAT from mature plants.

\begin{tabular}{|c|c|c|c|c|}
\hline \multirow{2}{*}{$\begin{array}{l}\text { Treatment } \\
\mu \mathrm{g} \text { ai L-1 } \\
\text { Young Plants }\end{array}$} & \multicolumn{2}{|c|}{$\frac{\text { Phytoene }}{\mu \mathrm{g} \mathrm{g} \mathrm{FW}-1}$} & \multicolumn{2}{|c|}{$\frac{\text { B-carotene }}{\mu \mathrm{g} \mathrm{g} \mathrm{FW}-1}$} \\
\hline & $\underline{28 \text { DAT }}$ & $\underline{56 \mathrm{DAT}}$ & $\underline{28 \text { DAT }}$ & $\underline{56 \text { DAT }}$ \\
\hline 0 & $33.1 \pm 5.20 \mathrm{~b}$ & $23.2 \pm 1.77 b$ & $25.2 \pm 2.49 \mathrm{a}$ & $38.7 \pm 2.45 \mathrm{a}$ \\
\hline 3-3-2 & $319 \pm 31.2 \mathrm{a}$ & $228 \pm 99.1 \mathrm{ab}$ & $23.1 \pm 2.21 \mathrm{a}$ & $19.5 \pm 1.13 b$ \\
\hline $4-2-2$ & $215 \pm 14.9 a b$ & $101 \pm 23.5 a b$ & $18.3 \pm 1.09 a b$ & $21.3 \pm 4.34 a b$ \\
\hline $4-4-2$ & $349 \pm 92.4 \mathrm{a}$ & $413 \pm 28.5 \mathrm{a}$ & $7.81 \pm 1.18 c$ & $24.0 \pm 4.29 a b$ \\
\hline $5-2-2$ & $394 \pm 33.0 \mathrm{a}$ & $117 \pm 38.3 \mathrm{ab}$ & $11.2 \pm 2.55 b c$ & $22.2 \pm 4.36 \mathrm{ab}$ \\
\hline $5-5-2$ & $334 \pm 103$ a & $-^{a}$ & $11.2 \pm 3.47 \mathrm{bc}$ & -1 \\
\hline $6-2-2$ & $202 \pm 72.1 \mathrm{ab}$ & $216 \pm 126 a b$ & $7.01 \pm 1.00 \mathrm{~b}$ & $30.8 \pm 2.73 a b$ \\
\hline Mature Plants & $\underline{28 \text { DAT }}$ & 49 DAT & $\underline{28 \text { DAT }}$ & 49 DAT \\
\hline 0 & $20.0 \pm 1.23 c$ & $28.3 \pm 6.51 d$ & $26.5 \pm 8.55 \mathrm{a}$ & $27.6 \pm 0.66 \mathrm{a}$ \\
\hline $3-3$ & $253 \pm 44.5 b$ & $142 \pm 17.0 \mathrm{bc}$ & $25.8 \pm 3.52 \mathrm{a}$ & $16.1 \pm 1.64 \mathrm{a}$ \\
\hline $4-2$ & $302 \pm 25.3 a b$ & $221 \pm 23.8 \mathrm{ab}$ & $19.4 \pm 2.48 \mathrm{a}$ & $24.9 \pm 4.61 \mathrm{a}$ \\
\hline $4-4$ & $468 \pm 38.0 \mathrm{a}$ & $148 \pm 8.38 b c$ & $21.4 \pm 4.95 \mathrm{a}$ & $8.31 \pm 2.15 \mathrm{a}$ \\
\hline $5-2$ & $318 \pm 95.1 \mathrm{ab}$ & $163 \pm 17.6 \mathrm{bc}$ & $12.0 \pm 3.02 \mathrm{a}$ & $16.6 \pm 4.95 \mathrm{a}$ \\
\hline $5-5$ & $295 \pm 115 a b$ & $269 \pm 47.3 \mathrm{a}$ & $16.6 \pm 2.24 \mathrm{a}$ & $15.4 \pm 5.21 \mathrm{a}$ \\
\hline $6-2$ & $225 \pm 43.9 b$ & $89.5 \pm 8.41 c$ & $10.0 \pm 0.59 a$ & $16.9 \pm 3.22 \mathrm{a}$ \\
\hline
\end{tabular}

Fluridone treatments of 4-2-2 and 4-4-2 $\mu$ gai $\mathrm{L}^{-1}$ reduced biomass by 52 and 61\%, respectively, at 72 DAT (Figure 9). These data support Minnesota field observations in Schutz and Eagle Lakes, where fluridone booster treatments of $4 \mu \mathrm{g}$ ai $\mathrm{L}^{-1}$ greatly reduced curlyleaf pondweed for as long as one year after treatment (Crowell et al. 2004). As in the previous greenhouse study, plants in this study were injured by a dose of $4 \mu \mathrm{g}$ ai $\mathrm{L}^{-1}$ for a 28-day exposure (Figures 4 and 6) ; however, the drop in fluridone concentrations from $4 \mu \mathrm{g}$ ai $\mathrm{L}^{-1}$ to $2 \mu \mathrm{g}$ ai $\mathrm{L}^{-1}$ was inadequate to sustain plant injury (Figure 9, Table 9) or inhibit production of stem turions (Table 10). 
Table 10. Number of axillary, stem and hard stem turions (mean $\pm 1 \mathrm{SE}$ ) produced by young and mature curlyleaf pondweed plants after 72 and 49 days exposure to fluridone,

respectively.

\begin{tabular}{|c|c|c|c|c|c|c|c|}
\hline \multirow{2}{*}{$\begin{array}{l}\text { Treatment } \\
\mu \mathrm{g} \text { ai } \mathrm{L}^{-1}\end{array}$} & \multicolumn{2}{|c|}{ Axillary Turions } & \multicolumn{2}{|c|}{ Stem Turions } & \multirow[b]{2}{*}{ Hard Stem } & \multirow[b]{2}{*}{ Total } & \multirow[b]{2}{*}{ \% Sprouting } \\
\hline & Mature & Immature & Mature & Immature & & & \\
\hline \multicolumn{8}{|c|}{ Young Plants } \\
\hline 0 & $1.67 \pm 1.67$ & $0.33 \pm 0.33$ & $0.67 \pm 0.67$ & 0 & 0 & $2.67 \pm 2.67$ & 100 \\
\hline $3-3-2$ & 0 & 0 & $0.33 \pm 0.33$ & 0 & 0 & $0.33 \pm 0.33$ & 100 \\
\hline $4-2-2$ & 0 & 0 & $0.67 \pm 0.6$ & $9.00 \pm 9.00$ & 0 & $9.67 \pm 8.68$ & 88.9 \\
\hline $4-4-2$ & 0 & 0 & 0 & 0 & 0 & 0 & - \\
\hline $5-2-2$ & $0.33 \pm 0.33$ & $1.67 \pm 1.67$ & $0.33 \pm 0.33$ & 0 & 0 & $2.33 \pm 2.33$ & 100 \\
\hline $5-5-2$ & 0 & 0 & 0 & 0 & 0 & 0 & - \\
\hline $6-2-2$ & 0 & 0 & 0 & 0 & 0 & 0 & - \\
\hline \multicolumn{8}{|c|}{ Mature Plants } \\
\hline 0 & $16.0 \pm 2.52$ & $8.33 \pm 2.03$ & $7.33 \pm 2.40$ & $2.00 \pm 0.58$ & $0.33 \pm 0.33$ & $34.0 \pm 6.24$ & $96.7 \pm 1.88$ \\
\hline $3-3$ & $24.3 \pm 16.6$ & $14.0 \pm 10.5$ & $6.00 \pm 3.22$ & $0.33 \pm 0.33$ & 0 & $44.7 \pm 29.9$ & $77.5 \pm 7.54$ \\
\hline $4-2$ & $4.33 \pm 2.19$ & $3.00 \pm 2.08$ & $2.67 \pm 1.45$ & 0 & 0 & $10.0 \pm 3.51$ & $97.4 \pm 2.56$ \\
\hline $4-4$ & $2.67 \pm 1.67$ & $1.67 \pm 1.20$ & $6.67 \pm 3.28$ & $3.33 \pm 3.33$ & $0.33 \pm 0.33$ & $14.7 \pm 9.74$ & $42.2 \pm 11.3$ \\
\hline $5-2$ & 0 & $1.67 \pm 1.67$ & $8.33 \pm 6.89$ & $14.7 \pm 14.7$ & $1.00 \pm 1.00$ & $25.7 \pm 24.2$ & $59.0 \pm 30.2$ \\
\hline $5-5$ & 0 & 0 & 0 & 0 & 0 & 0 & - \\
\hline $6-2$ & $5.33 \pm 4.84$ & $1.00 \pm 0.58$ & $2.67 \pm 1.45$ & $0.67 \pm 0.67$ & 0 & $9.67 \pm 5.78$ & $48.1 \pm 28.9$ \\
\hline
\end{tabular}

A fluridone concentration of $5 \mu \mathrm{g}$ ai $\mathrm{L}^{-1}$ for a 28-day exposure was insufficient to suppress curlyleaf pondweed growth following a decrease in concentration as shoots continued to elongate (Figure 10); however, $5 \mu \mathrm{g}$ ai $\mathrm{L}^{-1}$ for a 56 -day exposure reduced biomass by $87 \%$ at $72 \mathrm{DAT}$ (Figure 9) and eliminated turion production (Table 10). Allowing fluridone concentrations to drop to $2 \mu \mathrm{g}$ ai L $\mathrm{L}^{-1}$ during a critical period of exposure (the first two months) may result in greater shoot growth and turion numbers than would be acceptable for an operational treatment.

Fluridone treatment of 6-2-2 $\mu \mathrm{g}$ ai $\mathrm{L}^{-1}$ reduced shoot biomass by $93 \%$ at 56 DAT and $80 \%$ at 72 DAT (Figure 9), which verifies results of the previous greenhouse study, where a 6-3-6 treatment reduced young plant shoot biomass by $86 \%$ (Figures 4 and 6) . A 28-day exposure of $6 \mu \mathrm{g}$ ai $\mathrm{L}^{-1}$ followed by a dose of 2 or $3 \mu \mathrm{g}$ ai $\mathrm{L}^{-1}$ for another 28 days was effective in suppressing shoot elongation (Figure 10) and inhibiting turion production (Table 10). However, increased $\beta$-carotene levels at 56 DAT and the decrease in percent control from 56 to 72 DAT suggest that curlyleaf pondweed plants may recover from this treatment regime in the field. 


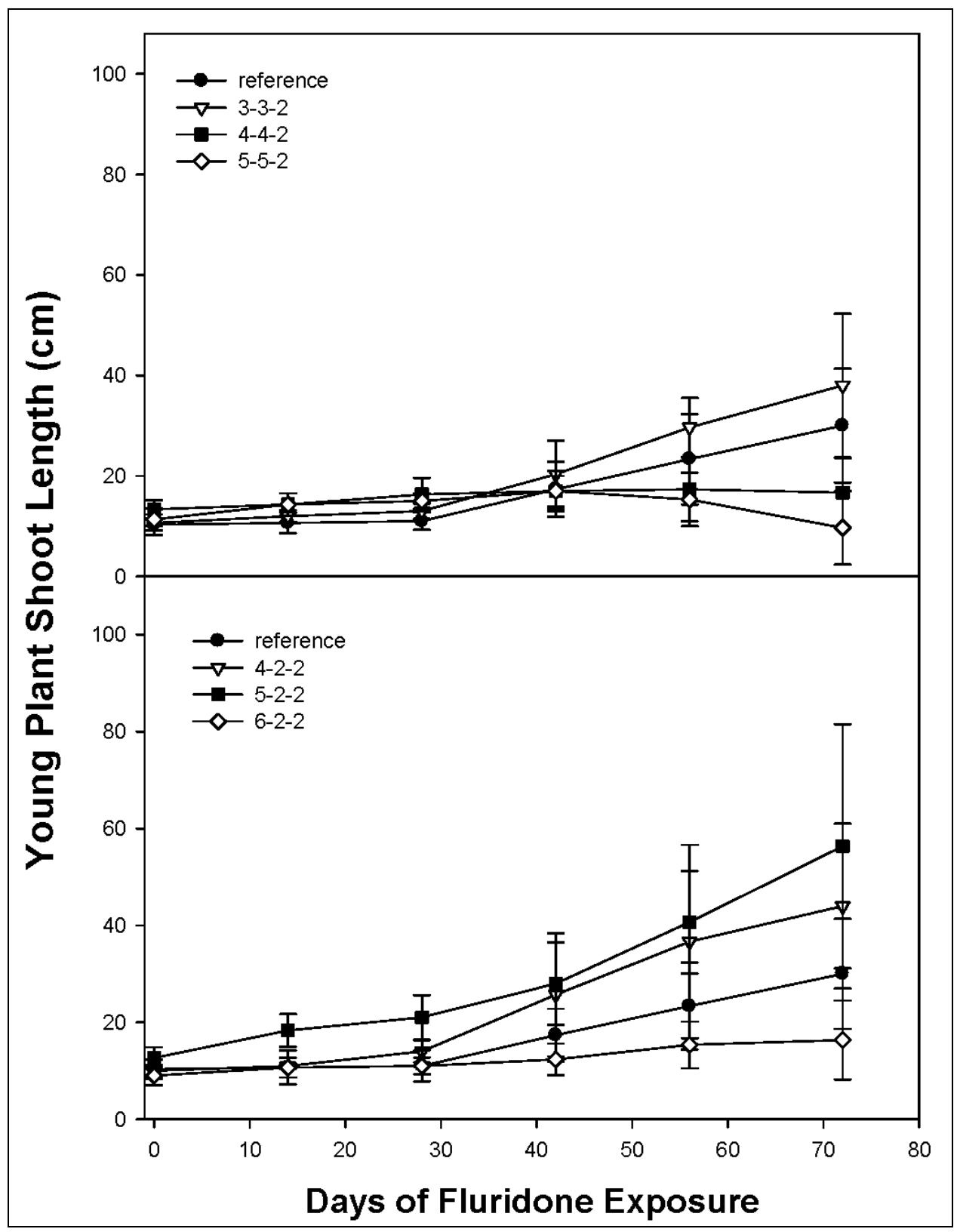

Figure 10. Shoot length (mean $\pm 1 \mathrm{SE} \mathrm{cm}$ ) of young curlyleaf pondweed plants after fluridone application.

\section{Mature Plant Growth and Turion Production}

Shoot biomass for mature curlyleaf pondweed plants is presented in Figure 11. Biomass of mature plants $(0.281 \pm 0.047 \mathrm{~g})$ was seven-fold higher than young plants $(0.041 \pm 0.004 \mathrm{~g})$ at herbicide application. Moreover, plant maturity in conjunction with warm water temperatures and long daylengths might have influenced how the plants responded to the fluridone treatment. Young plants that were treated with fluridone at water temperatures of $15^{\circ} \mathrm{C}$ remained below the water surface and 
generated less biomass than more mature plants. For mature plants, all except those in the 5-2 treatment continued to accumulate biomass through the end of the study. There were no statistical differences between treatments at $28 \mathrm{DAT}(\mathrm{F}=0.675, \mathrm{p}=0.673)$, and although there were no significant statistical differences between treatments at 49 DAT $(\mathrm{F}=2.397$, $\mathrm{p}=0.083$ ), control of curlyleaf pondweed ranged from 59 to $90 \%$ in all but the 3-3 and 4-2 $\mu \mathrm{g}$ ai $\mathrm{L}^{-1}$ treatments.

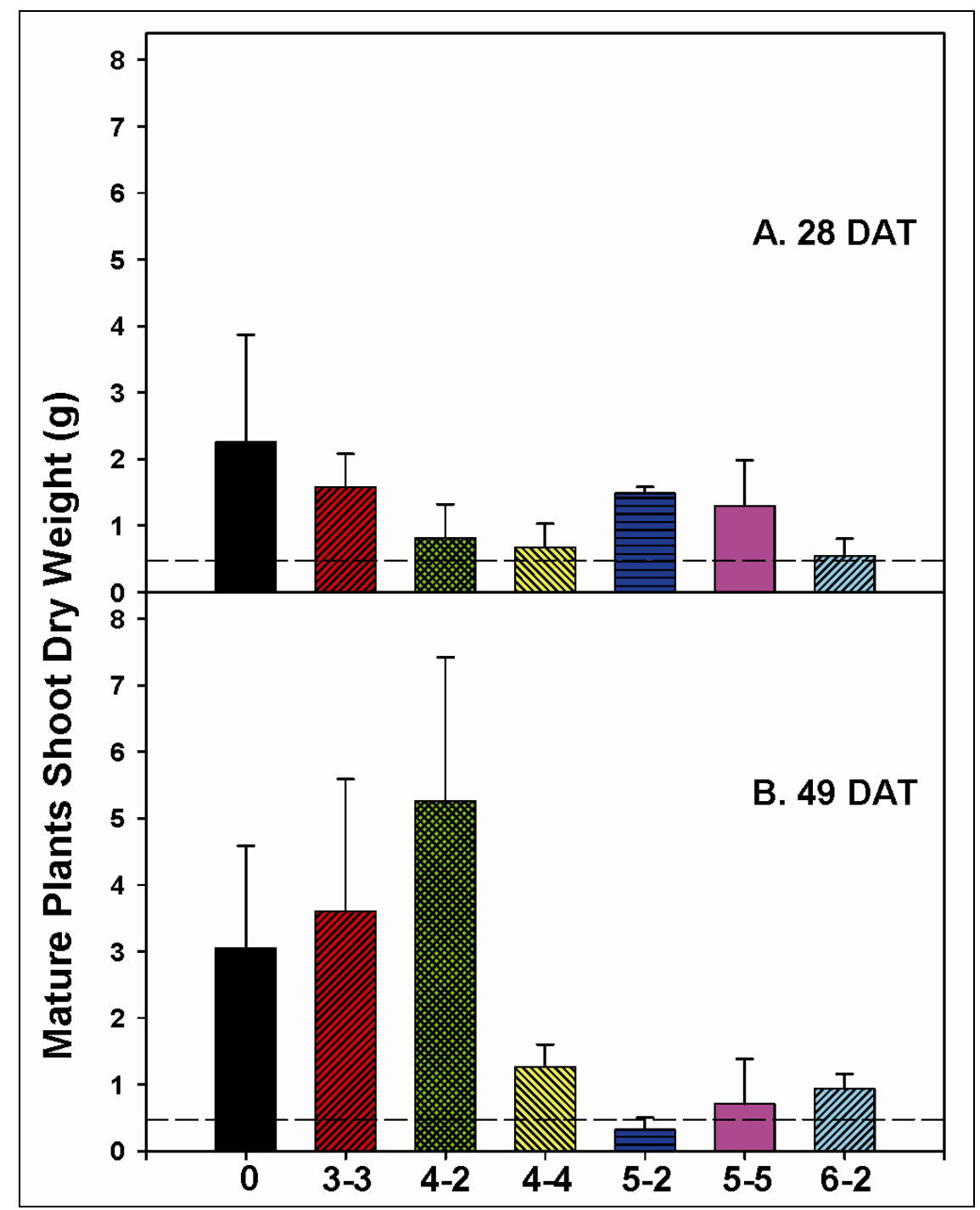

Figure 11. Mean ( $\pm 1 \mathrm{SE}$ ) shoot biomass $(\mathrm{g})$ collected from mature curlyleaf pondweed plants at A) $\mathbf{2 8}$ days after fluridone treatment (DAT) and B) 49 DAT. Dashed horizontal line indicates biomass at the time of treatment. 
Treatments from these lower herbicide concentrations/ exposure times generated 20 to $70 \%$ more biomass than the reference. Turion numbers were also higher in the 3-3 $\mu$ g ai L $\mathrm{L}^{-1}$ treatment, but not in the $4-2 \mu \mathrm{g}$ ai $\mathrm{L}^{-1}$ treatment (Table 10). Warmer water temperatures and increased day lengths probably stimulated growth of these mature plants, which mitigated fluridone impact when applied at these low doses.

Fluridone treatments of $4-4 \mu \mathrm{g}$ ai $\mathrm{L}^{-1}$ reduced biomass by $59 \%$ at 49 DAT (Figure 11). A constant exposure of $4 \mu \mathrm{g}$ ai $\mathrm{L}^{-1}$ for 49 days was sufficient to sustain plant injury (Table 9) and inhibit production of turions (Table 10). A longer exposure time to fluridone, even at a lower dose, such as $2 \mu \mathrm{g}$ ai $\mathrm{L}^{-1}$ probably would curtail shoot growth, as in the young plants, where shoot growth declined at 56 and 72 DAT. However, given the unusual life cycle of curlyleaf pondweed, applying herbicide for a long exposure time late in the growing season might compromise treatment efficacy with respect to natural plant senescence.

Shoot elongation for both the 5-2 and 5-5 treatments was less than the reference (Figure 12). The 5-5 $\mathrm{\mu g}$ ai $\mathrm{L}^{-1}$ treatment reduced biomass by $77 \%$ (Figure 11) and eliminated turion production (Table 10), and although a fluridone concentration of $5 \mu \mathrm{g}$ ai $\mathrm{L}^{-1}$ for a 28-day exposure followed by a lower dose of $2 \mu \mathrm{g}$ ai $\mathrm{L}^{-1}$ for 21 days suppressed growth, turions were present in treatment aquaria (Table 10).

The fluridone treatment of 6-2 $\mathrm{\mu g}$ ai $\mathrm{L}^{-1}$ reduced shoot biomass by $69 \%$ at 49 DAT (Figure 10) and inhibited turion production (Table 10). Percent sprouting of turions was less than $40 \%$ (Table 10). As with the younger plants, mature curlyleaf pondweed plants may recover from this treatment if applied in the field based on shoot growth (Figure 12) and $\beta$-carotene levels at 49 DAT (Table 9). 


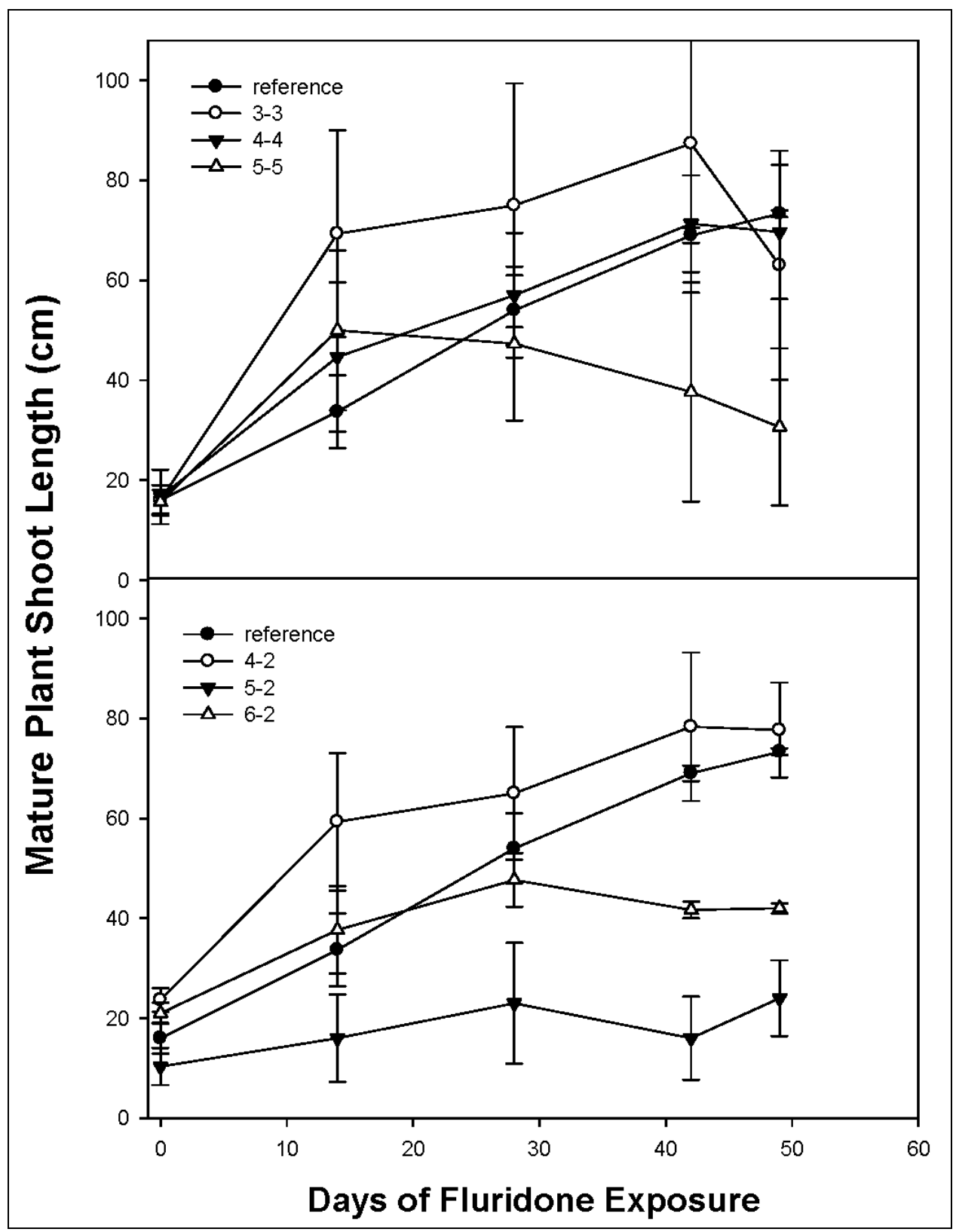

Figure 12. Shoot length (mean $\pm 1 \mathrm{SE} \mathrm{cm}$ ) of mature curlyleaf pondweed plants after fluridone application. 


\section{Conclusions and Recommendations}

\section{Conclusions}

Based on the results of these small-scale experiments, the following conclusions can be drawn about the effect of early season applications of fluridone on curlyleaf pondweed growth and reproduction:

a. Curlyleaf pondweed shoot biomass and turion numbers can be reduced with low fluridone doses and long exposure times. Exposure times can be extended by booster treatments. Sublethal doses or short exposure times will not provide adequate control nor inhibit turion production.

b. If turion production is not eliminated, these propagules will continue to serve as an annual source of reinfestation since turion viability was not affected by any of the fluridone treatments evaluated.

c. Fluridone has the potential to be used as a growth regulator of curlyleaf pondweed during the early spring when water temperatures are cool and plants are immature.

\section{Recommendations}

Based on the results of this investigation, the following recommendations are provided:

a. Fluridone treatments should be conducted with initial target concentrations of $\geq 4 \mu \mathrm{g}$ ai $\mathrm{L}^{-1}$ using exposure times of at least 56 days in which these target concentrations are maintained to ensure that shoot biomass is greatly reduced and turion production is adequately inhibited. Future studies that refine length of exposure times used with low fluridone doses would identify when booster treatments should be applied to maintain effective aqueous herbicide concentrations.

b. Fluridone treatments would be the most effective in suppressing curlyleaf pondweed growth and turion production if applications are conducted during the early spring when temperatures range from 15 to $20^{\circ} \mathrm{C}$, and plants are immature, well before the initiation of turion formation. Further investigation on the role of temperature, day length 
and plant maturity on turion formation and production after fluridone exposure would better define herbicide impacts on vegetative reproduction of curlyleaf pondweed.

c. Field verification of these small-scale experiments should be conducted in water bodies infested with curlyleaf pondweed. 


\section{References}

Chambers, P.A., D.H.N. Spence, and D.C. Weeks. 1985. Photocontrol of turion formation by Potamogeton crispus L. in the laboratory and natural water. New. Phytol. 99:183-194.

Crowell, W., C. Welling, and N. Proulx. 2004. Evaluation of the potential to selectively control Eurasian watermilfoil with fluridone herbicide in Minnesota: Results from 2001-2003. Draft report of the Minnesota Department of Natural Resources, St. Paul, MN.

Getsinger, K. D., J.D. Madsen, T.J . Koschnick, M.D., Netherland, R.M. Stewart, D.R. Honnell, A.G. Staddon, and C.S. Owens. 2001. Whole-lake applications of Sonar $^{\text {TM }}$ for selective control of Eurasian watermilfoil. ERDC/ EL TR-01-7. Vicksburg, MS: U.S. Army Engineer Research and Development Center.

Getsinger, K.D., J.D. Madsen, T.J . Koschnick, and M.D. Netherland. 2002. Whole-lake fluridone treatments for selective control of Eurasian watermilfoil: I. Application strategy and herbicide residues. Lake and Reserv. Manage. 18:181-190.

Getsinger, K.D., and M.D. Netherland. 1997. Herbicide concentration/ exposure time requirements for controlling submersed aquatic plants: Summary of research accomplishments, Miscellaneous Report A-97-2. Vicksburg, MS: U.S. Army Engineer Waterways Experiment Station.

Kunii, H. 1989. Continuous growth and clump maintenance of Potamogeton crispus L. in Narutoh River, J apan. Aquat. Bot. 33:13-26.

Madsen, J .D., K.D. Getsinger, R.M. Stewart, and C.S. Owens. 2002. Whole-lake fluridone treatments for selective control of Eurasian watermilfoil: II. Impacts on submersed plant communities. Lake and Reserv. Manage. 18:191-200.

Netherland, M.D., and K.D. Getsinger. 1995a. Laboratory evaluation of threshold fluridone concentrations under static conditions for controlling hydrilla and Eurasian watermilfoil. J . Aquat. Plant Manage. 33:33-36.

Netherland, M.D., and K.D. Getsinger 1995b. Potential control of hydrilla and Eurasian watermilfoil under various half-life scenarios. J . Aquat. Plant Manage. 33:36-42.

Netherland, M.D., K.D. Getsinger, and J .G. Skogerboe. 1997. Mesocosm evaluation of the species-selective potential of fluridone. J . Aquat. Plant Manage. 35:41-50.

Netherland, M.D., K.D. Getsinger, and E.G. Turner, E.G. 1993. Fluridone concentration and exposure time requirements for control of Eurasian watermilfoil and hydrilla. J . Aquat. Plant Manage. 31:189-194.

Netherland, M.D., D.R. Honnell, A.G. Staddon, and K.D. Getsinger. 2002. Comparison of immunoassay and HPLC for analyzing fluridone concentrations: New applications for immunoassay techniques. Lake and Reserv. Manage. 18: 75-80. 
Netherland, M.D., J .G. Skogerboe, C.S. Owens, and J.D. Madsen. 2000. Influence of water temperature of the efficacy of diquat and endothall versus curlyleaf pondweed. J . Aquat. Plant Manage. 38:25-32.

Poovey, A.G., J.G. Skogerboe, and C.S. Owens. 2002. Spring treatments of diquat and endothall for curlyleaf pondweed control. J . Aquat. Plant Manage. 40:63-67.

Sastroutomo, S.S. 1980. Environmental control of turion formation in curly pondweed (Potamogeton cripus). Physiol. Plant. 49:261-264.

Skogerboe, J .G., A.G. Poovey, K.D. Getsinger, W. Crowell, and E. Macbeth. 2006. Early season, low dose applications of endothall to selectively control curlyleaf pondweed in Minnesota lakes. APCRP Technical Notes Collection. ERDC TN/APCRP-CC-00. Vicksburg, MS: U.S. Army Engineer Research and Development Center.

Smith, C.S., and G.D. Pullman. 1997. Experiences using Sonar ${ }^{\circledR}$ A.S. aquatic herbicide in Michigan. Lake and Reserv. Manage. 13(4):338-346.

Sprecher, S. L., M.D. Netherland, and A.B. Stewart. 1998. Phytoene and carotene response of aquatic plants to fluridone under laboratory conditions. J . Aquat. Plant Manage. 36:111-120.

Woolf, T.E., and J.D. Madsen. 2003. Seasonal biomass and carbohydrate allocation patterns in southern Minnesota curlyleaf pondweed populations. J . Aquat. Plant Manage. 41:113-118. 


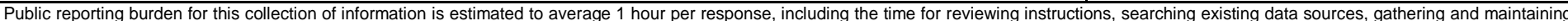

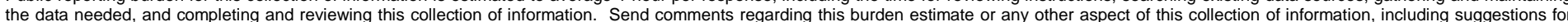

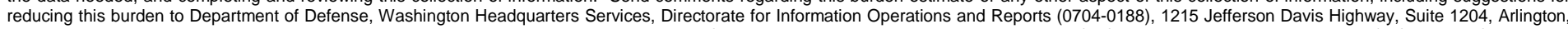

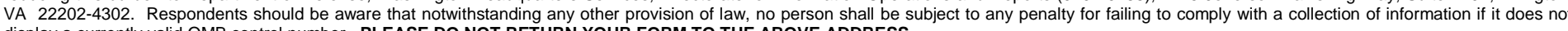
display a currently valid OMB control number. PLEASE DO NOT RETURN YOUR FORM TO THE ABOVE ADDRESS.

\section{REPORT DATE (DD-MM-YYYY) 2. REPORT TYPE \\ \begin{tabular}{l|l} 
December 2010 & Final report
\end{tabular}}

\section{TITLE AND SUBTITLE}

Early Season Applications of Fluridone for Control of Curlyleaf Pondweed

6. AUTHOR(S)

Angela G. Poovey, Lee Ann M. Glomski, Michael D. Netherland, and John G. Skogerboe

\section{PERFORMING ORGANIZATION NAME(S) AND ADDRESS(ES)}

U.S. Army Engineer Research and Development Center

Environmental Laboratory

3909 Halls Ferry Road

Vicksburg, MS 39180-6199

\section{SPONSORING I MONITORING AGENCY NAME(S) AND ADDRESS(ES)}

Headquarters, U.S. Army Corps of Engineers

Washington, DC 20314-1000

\section{DISTRIBUTION / AVAILABILITY STATEMENT}

Approved for public release; distribution is unlimited.
3. DATES COVERED (From - To)

5a. CONTRACT NUMBER

5b. GRANT NUMBER

5c. PROGRAM ELEMENT NUMBER

5d. PROJECT NUMBER

5e. TASK NUMBER

5f. WORK UNIT NUMBER

8. PERFORMING ORGANIZATION REPORT NUMBER

ERDC/EL TR-10-22

10. SPONSOR/MONITOR'S ACRONYM(S)

11. SPONSOR/MONITOR'S REPORT NUMBER(S)

\section{SUPPLEMENTARY NOTES}

\section{ABSTRACT}

Widespread in the Great Lakes region, curlyleaf pondweed (Potamogeton crispus L.) is an exotic submersed plant that forms dense monotypic stands, and is reported to restrict recreation, suppress native plant populations, and increase internal phosphorus cycling. Because preventing new turion formation is the key to long-term management of this aquatic weed, the effect of fluridone applications on curlyleaf pondweed growth and vegetative reproduction was evaluated in two greenhouse studies. Herbicide doses ranged from 0.5 to $6 \mu \mathrm{g}$ ai $\mathrm{L}^{-1,}$ and were applied to plants of different growth stages for varying exposure times. Fluridone doses $\geq 5 \mu \mathrm{g}$ ai $\mathrm{L}^{-1}$ that were maintained for at least 28 days before degrading to $\leq 2 \mu \mathrm{g}$ ai $\mathrm{L}^{-1}$ inhibited both shoot growth and turion production. Treatments of 3 and $4 \mu \mathrm{g}$ ai $\mathrm{L}^{-1}$ that degraded to $\leq 2 \mu \mathrm{g}$ ai $\mathrm{L}^{-1}$ after 28 days reduced turion number, but not shoot biomass. All treatments $\leq 2 \mu \mathrm{g}$ ai $\mathrm{L}^{-1}$ were comparable to the reference. Although young plants that were $<15 \mathrm{~cm}$ at herbicide application remained below the water surface, they produced the same amount of turions as mature plants that were $>15 \mathrm{~cm}$ at the time of application. Sprouting tests determined that turions from all fluridone treatments were viable. Based on these results, strategies for curlyleaf pondweed management may include fluridone applications to young plants using rates that would curtail turion production and either prevent or limit nuisance shoot growth.

\section{SUBJECT TERMS}

Aquatic plant control

Curlyleaf pondweed

16. SECURITY CLASSIFICATION OF:

\begin{tabular}{|l|l|l|}
\hline $\begin{array}{l}\text { a. REPORT } \\
\text { UNCLASSIFIED }\end{array}$ & $\begin{array}{l}\text { b. ABSTRACT } \\
\text { UNCLASSIFIED }\end{array}$ & $\begin{array}{c}\text { c. THIS PAGE } \\
\text { UNCLASSIFIED }\end{array}$ \\
\hline
\end{tabular}

Fluridone

Herbicides

17. LIMITATION
OF ABSTRACT

\section{NUMBER OF PAGES}

45 19a. NAME OF RESPONSIBLE PERSON

19b. TELEPHONE NUMBER (include area code) 